\title{
Coordination for Policy in Transition Countries: Case of Croatia
}

\author{
Anamarija Musa \\ Faculty of Law, University of Zagreb, Croatia \\ amusa@pravo.hr \\ Zdravko Petak \\ Faculty of Political Science, University of Zagreb, Croatia \\ zdravko.petak@fpzg.hr
}

\section{ABSTRACT}

The formulation and implementation of public policy depends on the coordination capacities. In recent decades the need for coordination has increased due to the fragmentation caused by NPM reforms, decentralisation processes, the proliferation of the cross-cutting issues, as well as increased globalisation, Europeanisation, and professionalization. The coordination problem in Croatian administration, similarly to other transition countries, is critically important but understudied. This paper is based on a preliminary research on coordination in Croatian public administration with regard to policy formulation and implementation of three policies - regional development policy, anticorruption policy and e-government policy, based on the interviews conducted with higher civil servants and public officials. A special emphasis is given to the role which various actors play in coordination, as well as the structures Government employs in order to coordinate. The research shows that the development of coordination instruments in Croatia suffers from inefficiencies and is greatly influenced by politically driven considerations.

Keywords: coordination, public policy, anti-corruption policy, e-government policy, regional development policy

JEL: $H 11, H 83$

\section{Introduction $^{1}$}

The problem of coordination in public administration is a well known and constant concern of both scholarly literature and practice. The processes of fragmentation of state administration, political decentralisation as well as increased international cooperation within the framework of globalisation and Europeanisation have increased the problem of coordinating public

1 The first version of the paper was presented at the RC 27 Structure and Organization of Government, 22 ${ }^{\text {nd }}$ IPSA World Congress, 8-12 July 2012, Madrid, Spain. 
policies and attaining the goals of public administration. In addition, several urgent societal problems have been addressed within a new type of public policies which cut across existing policy areas and ministerial portfolios, such as environmental protection, gender equality, economic competition or anti-corruption (Bogdanor, 2005; Bouckaert, Peters, \& Verhoest, 2010). Consequently, the problem of coordination immanent to every policy became the central administrative and policy problem of the modern societies and the governance approach which advocates a broad inclusion of different actors in both policy formulation and policy implementation process.

In developing democracies and public administrations the coordination issues become even more visible (Matei \& Dogaru, 2013; Saner et al., 2008; James \& Staronova, 2003; Staronova, 2002). The building of adequate coordination structures and developing the instruments of coordination has been one of the main elements of state and administration reforms, especially in the Central and Eastern Europe (hereinafter CEE). The inherited coordination mechanism based on the transfer of decision-making from the communist party to the state institutions via the political appointees in the political bodies and administration (nomenclature) could not respond to the new political, social and economic environment in the transition period and processes of opening up to the society, democratization, Europeanisation and internationalization. In the new political and economic context it became necessary to develop and to institutionalize coordination structures and functions which would connect government horizontally and vertically and ensure transparent and effective decision making and implementation.

This paper examines the problem of coordination in Croatia in three distinctive policies which cut across different sectors, enhancing the need for coordination at the highest administrative and political levels - the regional development policy, the anti-corruption policy, and the e-government policy. Special emphasis is put on the evolution of political and administrative structures of coordination, the actors included in coordination of policies and the impact of the EU on the development and the success of coordination. The coordination in Croatian public administration is generally assessed as weak, especially at the level of central state administration (Petak, 2009; Petak \& Petek, 2009). The problem of coordination of policy in both formulation and implementation phase might be connected to the shortcomings (or absence) of the strategic management in government. The paper will try to address the following questions: What kind of coordination structures and instruments are used and what problems do specific policies encounter with regard to the coordination? The answers are based on the data gathered by the analysis of legal documents and interviews with several top civil servants.

The paper is structured as follows. In chapter 2 the issue coordination is analysed, first in relation to contemporary governance, then with regard to the policy formulation and implementation, and finally as an organisational concept. In chapter 3 the problem of coordination in transition countries 
is presented, with special emphasis on Croatia. The research framework is conceptualized and the findings are presented and discussed. In chapter 4 some conclusions and prospects for further research are drawn.

\section{The Review of the Coordination Issue}

\subsection{The Central Role of Coordination in Modern Societies}

The problem of coordination is a well-known but understudied problem in public administration literature. The classical administrative thought has argued that the trends of specialisation and both horizontal and vertical differentiation of administrative activity in modern state cause an increased need for coordination as well as integration (see Pusić et al., 1988). By specialisation we assume the process of creation of new administrative organisations out of traditional monolithic departments which may have conflicting goals or objectives (Pollitt \& Bouckaert, 2004; Verhoest, Bouckaert, \& Peters, 2007). The specialisation can be horizontal, if it emerges at the same administrative level, or vertical, when it allocates tasks on different hierarchical levels, usually under the terms of decentralisation, devolution or delegation. As a consequence of specialisation, Gulick's motto "influence outcomes" by "working together for a common purpose" accentuated the importance of coordination regardless of criteria of specialisation - geography, task, clientele, process (Meier, 2010; Christensen \& Laegreid, 2008). Few decades later Thompson (1967) as well as Mintzberg (1979) confirmed one of the key hypotheses of organisation theory that specialisation and differentiation put pressure on coordination (Verhoest et al., 2007, p. 326) creating organisational domains which have to be reconciled in order to achieve common goals.

Still, the importance of coordination in the system of governance has risen tremendously in recent decades. The New Public Management (NPM) exacerbated the specialisation trend by pleading for the differentiation, delegation, devolution and decentralisation to independent agencies, outsourcing to private sector organisations, as well as the privatisation of public services. The idea that relatively autonomous specialised organisation would help achieve effectiveness and efficiency of public sector led to the disaggregation and atomisation of public sector, with complex relations between ministries and agencies, sometimes based on contractual relationship and performance control. Splitting policy and administrative tasks in different types of administrative organisations (ministries versus agencies) is one of the main NPM goals (Hood, 1991). Parallel to that, the process of decentralisation to local units has transferred the responsibility for delivery of services to regions and local units. In this sense, P. 6 (2004, p. 107) accentuates that the importance of coordination in contemporary governance systems does not emerge from mere specialisation, but from fragmentation which exacerbates "lack of good conflict management" and "inadequately structured relationship between specialties". 
Another incentive for paying greater attention to coordination is found in the emergence of special kind of policy problems, most of which are connected to increased customer orientation and focus on service delivery (Verhoest et al., 2007; Christensen \& Laegreid, 2007; P. 6, 2004). First, the cross-cutting issues which mark contemporary societies add to already complex web of structures, relations and processes. The term relates to the horizontal policies such as environmental protection, sustainable growth, minority rights, but also those related to specific groups, such as elderly, disabled persons, unemployed, etc. (see Peters, 1998, p. 11). Contemporary societies face the whole range of 'wicked problems' that have to be dealt and solved by joint effort of different organisations, layers of government, and sector areas. Weber and Khademian (2008) define three characteristics of wicked problems: they are unstructured, because they do not exhibit clear cause-effect relationship but show complexity which challenges traditional way of solving problems; they are crosscutting, because they include different elements which relate to different policy areas and actors and cannot be dealt by one department; finally, they are relentless, in the meaning that they can hardly be solved, but their direct or indirect consequences are felt in concentric circles around main problem. Hence, the main goal is to tackle a part of the problem in order to decrease its intensity. Examples include drug abuse, security issues, reducing crime, homelessness, etc, as "highly complex and intractable social problems" (Keast, Mandell, Brown, \& Woolcock, 2004).

The coordination issue is especially accentuated with regard to the processes of globalisation, Europeanisation and professionalisation, but also the recent economic and security crisis (Christensen \& Laegreid, 2007). Globalisation influences the degree of coordination, since it puts pressure on the efficiency of governments to solve social problems, boost economy and ensure social development. Joint efforts are needed to achieve advanced position in comparison to other competitors, followed by the proliferation of specialised international and regional organisations. Similarly, in the EU policy making, the issue of coordination emerges as a prerequisite of successful membership in terms of EU policies formulation and implementation, as well as with regard to the coordination of various policy sectors among the levels of European governance. Moreover, professionalisation as a form of specialisation in connection to the processes of globalisation and information technology revolution enhances creation of professional networks which spread well beyond boundaries of state and even profession itself. The new forms rest upon a new type of coordinating philosophy, on shared values and interests and seeks for creation of new coordinating instruments. Finally, the importance of coordination arises in times of economic crisis, but also in times of the enhanced stress for the security. The reorganisations and rationalisation programmes launched in last few years in many countries, had the task to examine and re-set the priorities as well as to simplify the structures and procedures which often led to mergers and abolitions of previously overlapping structures and multiplied tasks. The fiscal pressure 
to decrease public spending has political implications - inefficiencies in public sector cost more than in private sector, not only wasting public money but also leaving citizens deprived of service. In addition, natural catastrophes and security threats have put enormous pressures to the development of coordinative functions of crisis management in order to enhance prevention or to make the problem-solving process more efficient.

As a response to NPM driven fragmentation, which in the above mentioned context has reinforced the pillarisation and siloisation of public sector, the post-NPM reforms have been increasingly focused on joining-up the pillars of administrative activity. In the second half of the 1990s the programs of whole-of-government (Christensen \& Laegreid, 2007), joining-up (Davies, 2009; Pollitt, 2003; Bogdanor, 2005) or holistic government (P. 6, 2004) have emerged as a solution which should enhance effectiveness of policy work and help to solve problems facing modern states. The strengthening the coordination capacity has focused not only on hierarchical mechanisms, but also on networks and markets, as alternatives to authoritative top-down approach (Verhoest et al., 2007), but with path dependent trajectories (Beuselinck, Verhoest, \& Bouckaert, 2006; Hustedt \& Tiessen, 2006). The concept of 'joined-up government' was defined by Pollitt (2003, p. 35) "as phrase which denotes the aspiration to achieve horizontally and vertically coordinated thinking and action" in order to eliminate contradictions between policies, achieve better use of resources, improve cooperation, and produce integrated services.

When it comes to the joined-up government efforts as well as the coordination in the administrative system, different factors are found to be relevant. For example, 6 (2004, pp. 110-112) accentuates five variables as being of importance for the emergence of joining-up efforts: the importance of particular events (such as terrorist attack), the type of political system (Rechtstaat or public interest principle, which is more in favour of coordinative efforts), national political-administrative cultures (Anglo-Saxon countries are seen as being more in favour of joining-up) and path dependency plus negative feedback, in the meaning of adopting coordination strategies in order to correct the failures of reform. Similarly, Bouckaert et al. (2010) argue that explanatory factors can be found in the politico-administrative traditions, type of responsibility (minister vs. collegium), position of the horizontal departments, the size of a country, and the type of agencification.

\subsection{The Importance of Coordination for Policy Formulation and Implementation}

The process of developing specific adjective or sector policies involves various stages, with different number of the participants at each of the particular stage, which makes policy analysis an extremely complex discipline. The process of governing policy issues assumes several structural preconditions. The most prominent is the idea of instrumentality, indicating that government 
is obliged to find solutions to social problems. Other assumptions follow from this one. The first is coherence, in the sense that "all the bits of the action should fit together and form part of an organized whole" (Colebatch, 2009, p. 10). The second relates to the idea of hierarchy, indicating that governing is accomplished by the application of authority. The issue of policy coordination stems from the account pointing out the question of coherence, having in mind that 'much policy work is concerned with the way different agencies handle the same policy issues' (Colebatch, 2009, p. 9). From this standpoint of view policy coordination can be defined as the efforts aimed to synchronization and integration of developing and implementing public policy. ${ }^{2}$

The problem of policy coordination is particularly pertinent for the formulation and implementation of particular policy. The insufficient coordination between policy-stakeholders in the process of formulating policy, as well as failure to coordinate implementation activities can be labelled as the core problem of policy. Coordination in the stage of formulation includes numerous activities related to the preparation of policy proposals, the preparation of legal drafts, the inter-ministerial consultations, the submissions of these proposals to government office, the review of these policy documents by the office, as well as the final review by governments' commissions and the inner cabinet (OECD, 2007). The similar can be applied to implementation, having in mind that the efficient implementation, from the top-down view, relies on several preconditions: clearly defined policy objectives and goals, available resources and clearly defined policy instruments and capacity for monitoring and coordination of particular policies (Sabatier, 1986).

There are several dimensions of policy coordination which are studied within the disciplines of administrative science and policy sciences. These dimensions include differences between positive and negative aspects of coordination, vertical and horizontal lines of coordination, short-term and long-term aspects of achieving coherence of the policy goals, and finally the different meaning of the coordination in issues related to the policy and issues related to the administration (Peters, 2015, pp. 9-19). For the purpose of our study it is particularly interesting to make a clear distinction between political and administrative coordination, which directly originates from the previously mentioned difference between administration and policy. The bottomup approach to coordination indicates "the role administrators can play in producing effective coordination", while pointing out political angle stresses the fact that legitimacy and power for running policies "may be vested in political leaders rather than in administration" (Peters, 2015, p. 14). One can speak of horizontal and vertical policy management. The former relates

2 Peters distinguishes between four levels of coordination. The first relates to negative coordination (involving coping with the situations in which government programs and organizations overlapping), followed by the positive coordination (finding ways of collaborative actions of government bodies in order to provide better services for the clients), policy integration (which includes coordinating the goals being pursued by public organizations and not only service delivery) and development a strategies for government, as a most complex form of coordination (Peters, 2004, pp. 5-6). 
to coordination among participators from different policy fields at the same governmental level, whereas the latter relates to coordination of different levels of government. The horizontal guidelines pertain to organisational cooperation and help to remove obstacles hindering the efficient interaction amongst administrative bodies in particular policy fields, while the vertical guidelines pertain to linking the objectives, structures and resources in order to establish a relation between strategy and service delivery. The importance of vertical policy coordination has been strongly enhanced by the side-effects of Europeanisation, which is firmly based on the concept of multi-level governance.

Therefore, the activities relating to formulation, as well as to implementation of a particular policy require different levels of coordination. Since the government mechanism does not stand as a single body, but rather consists of organisations which are to a different degree mutually inter-connected, the coordination exercise reflects the ideas of efficient interaction between various parties in an effort to work together toward a common goal. In doing so, policy coordination involves various procedures and structures, such as an efficient consultation system and the role of policy expertise in government office, the role of cabinet committees in coordinating policies, the establishment of central agencies, coordinative efforts across ministries and many other forms. Moreover, one can speak of instruments of coordination, which can include the organisation of the core executive, the structure of chief executive staff, central policy agencies, functioning of cabinet or primeminister office and the role of cabinet committees in policy coordination (Peters, 2015).

The next question accounts for the measurement and degrees of coordination. In the literature Metcalfe's classification of policy coordination (Metcalfe, 1994) is widely employed dealing with hierarchically developed phases of policy coordination, determining the intensity of coordinative efforts along nine dimensions which measure the coordination capacity. The scale relates to "a series of steps, which add successive coordination functions in a specific logical sequence" (Metcalfe, 1994, p. 281). The lowest level of coordination relates to the (1) independent organisational decision making, where each organisation retains autonomy within its own policy domain, based on their own legal and political prerogatives; on the next level, organisations are obliged to (2) communication to other organisations (information exchange), to inform others about issues and proposed actions; the quality of channels of communication plays a role; on the next level (3), organisations are using consultation with other organisations, which includes seeking for and giving advice to other organisations in the process of formulating policies; next, (4) avoiding divergences among ministries, on the next level, focuses on eliminating divergent negotiating positions (a negative coordination); (5) inter-organisational search for agreement (seeking consensus), is trying to make organisations work together, reaching consensus; joint 
committees and project teams are used; next step (6) relates to arbitration of inter-organisational differences, where the contradictions or conflicts are being resolved by a third party; more than this, (7) setting parameters for organisations, happens when a central organisation gets more active, by setting parameters on the discretion of individual organisations, such as budgetary or regulatory constraints; (8) establishing government priorities, relates to the active steering by setting clear priorities and coherent framework for lower levels; finally, (9) an overall governmental strategy is the case which is rare in practice, but would create totally unified system, with decision about choices. Positive coordination includes higher levels of coordination, from seven to nine, and all actions in earlier stages are still being considered as a negative coordination (Metcalfe, 1994, pp. 281-284).

An extremely important line in policy coordination research relates to national case-studies, showing the peculiarities of coordinating public policies in different national administrative systems. Among this kind of literature a few studies should be mentioned, covering several developed democracies - four OECD countries: New Zealand, United Kingdom, Sweden, France (Verhoest et al., 2007), seven OECD countries: New Zealand, United Kingdom, Sweden, the Netherlands, France, Belgium and the United States (Bouckaert et al., 2010). Besides this research there is a list of numerous national case-studies with in-depth analysis of policy coordination achievements in particular developed democracies: Australia (Painter, 1981), Canada (Hopkins, Couture, \& Moore, 2001; Peach, 2004), Finland (Pelkonen, Teräväinen, \& Waltari, 2008), etc. For the purpose of our paper the findings related to post-communist countries should be mentioned, like the review of Romanian case (Matei \& Dogaru, 2013) or the case of several post-communist countries (Saner et al., 2008). The proliferation of policy coordination studies deeply oriented to institutional arrangements in particular countries could be extremely helpful in refining theoretical statements on coordination issues, particularly the effectiveness of policy coordination measures.

\subsection{An Overview of the Concept of Coordination - Types, Mechanisms, Structure, and Instruments}

There are different approaches to coordination. The choice of perspective depends on the theoretical framework and the aim of the particular research. For example, from the point of public sector inter-organisational coordination is perceived as "the instruments and mechanisms that aim to enhance the voluntary or forced alignment of tasks and efforts of organisations within the public sector. These are used in order to create a greater coherence and to reduce redundancy, lacunae and contradictions within and between policies, implementation or management" (Peters, 1998). From the policy perspective, coordination is an "attempt to produce coherent government policies and achieve a state that minimizes conflicts that arise between different government organisations (mainly ministries) over programs, proposals or 
legislative bills", while coherent government policies are political programs "free of contradictions both within every single policy and in the whole of governmental programs" (Hustedt \& Tiessen, 2006, p. 5).

In order to explore the subject more thoroughly, many attempts have been made to differentiate between kinds of coordination based on whole range of criteria.

- depending on the level and the direction, there are political (or policy) and administrative coordination; ${ }^{3}$ roughly, although it is more of a "false dilemma" (Peters, 1998), administrative coordination is bottomup approach, implementation bound and oriented towards delivery of final result (service), while policy coordination, is top-down approach, confined to political level and oriented towards general performance of policy or system (see Peters, 1998; 2005; Davies, 1998); ${ }^{4}$

- depending on the scope, intra-policy coordination, related to one policy area formulation and implementation, while inter-policy coordination cuts across many policy fields (see Verhoest et al., 2007, p. 330)

- depending on the kind of relationship between responsible departments, the negative coordination might relate to passive attitude of avoiding conflicts between policy areas, and, if they emerge, solving the problem by the department specialised in respective policy; on the other side, positive coordination implies active approach based on joint efforts to solve identified contradictions or problems, based on mutual supporting and cooperating schemes, rules, frames and systems (see Peters, 2005; Hustedt \& Thiessen, 2006);

- depending on policies covered, vertical coordination is confined in one policy area with many levels (including supranational level), while horizontal includes coordinating at the same level across different policy areas, with central government and supporting departments having significant power to ensure that their centripetal activities have a desired effect (Christensen \& Laegreid, 2008, p. 102);

- depending to the involvement of actors, coordination may relate to different government organisations within own area of work; with government organisations in other policy areas; with local and regional government; with supra/international organisations; with private sector companies or interest organisations and civil society (see Christensen \& Laegreid, 2008).

3 Hustedt and Thiessen (2006) make distinction between administrative coordination which is pursued by civil servants in the beginning stage of coordination process, based on professional orientation, expertise, department tradition, individual incentives, and search for policy solution); and political coordination, at political level, which is determined by various factors, such as party politics, goals, re-election incentives, etc., often including informal instruments; somewhere in between is political-administrative coordination.

4 Davis (1998) distinguishes between three types - political coordination, in the meaning of the necessity that the government ministers share common objectives and rhetoric; policy coordination, in the meaning of setting goals and objectives and preventing contradictions between policies; and administrative, the orientation for effectiveness and efficiency in accomplishing tasks determined by the government. 
Coordination rests upon two basic mechanisms. Peters (1998) distinguishes imposition and bargaining as two sides of coordination, depending whether the process is more participative or hierarchical. However, the mechanisms follow two strands in neoinstitutionalist thinking, although titles may be different (coercion and competition; compliance and competition, etc.). Still, contrary to the traditional way of thinking that the government should function by imposition and enforce certain behaviour by hierarchical means, the modern governments lean on competitive forces or professional networks in order to achieve coordination for the sake of public interest. The conventional typology includes hierarchy, markets and networks, a distinction made by Thompson et al. in 1991, and frequently employed by others (see Peters, 1998, 2009, 2015; Verhoest et al., 2007; Hood, James, Peters, \& Scott, 2004):

1. hierarchy is based on authority, imposition and coercion, top-down interactions and is supported by political and administrative leadership (Peters, 1998, p. 17; Verhoest et al., 2007); it involves setting rules, goals and defining tasks together with lines of responsibility and supervision (auditing, inspection, political and administrative control); it is directed towards resolving conflicting interests and achieve systemic goals, but, at the same time, it involves costs that administrators may define as unnecessary burden (Peters, 2008);

2. market is based on exchange, price or reward, and competition; markets are institutions of coordination (Peters, 2005: 9), creating incentives for actors to behave in certain way; they can be created under government umbrella (regulated markets), which is one of the effects of NPM reforms (internal markets, managerial contracts, PPP), as well as the EU (regional policy, structural funds, science and research, etc.);

3. network rests upon shared values, beliefs and norms, as well as the trust among the participants; it is usual in professional activities, around same policy issues; the network arrangements may evolve spontaneously, but they can be created or supported by the authority, by creating informational base, or fostering partnership or collaboration; still, this type contains a degree of self-regulation (creating standards, peerreview, etc.).

The adequacy of each mechanism depends on type of policy, phases of policy, or kind of actors involved. For example, networks are more suitable for formulating policies on the bases of shared objective, while hierarchical coordination will be better in relatively closed system, which does not need the inclusion of external actors.

Some authors add a fourth type or use different symbols to differentiate between mechanisms based on authority or sanctions, price or rewards and trust and shared objectives. Peters (2005) differentiates between market, networks, collaboration and hierarchy; Hood (2005) differentiates between 
authority, architecture, mutual interaction and market and price systems; Hood et al. (2004) make distinction between oversight, competition, mutuality and, as a fourth type, contrived randomness which involves unsystematic, non-predicted processes of cooperation, without clear strategy, and expects unilateral responses to the coordinated action. Similarly, P. 6 (2004, p. 116) defines four mechanisms of coordination, depending of the type of constraint (strong or weak) and the type of bond (strong or weak): hierarchy, individualism, mutuality and subaltern isolates (randomness).

In sum, types of coordination involve different organisational/structural and functional/procedural instruments which are more suitable to certain type of mechanism, but can be employed by others too (see Peters, 1998; Verhoest et al., 2007; Bouckaert et al., 2010; Christensen \& Laegreid, 2008). Structural/ organisational means are aimed to enhance coordination and to close it within organisational boundaries or to use the organisation as a centre of coordinating activity. Examples include centres of government, secretaries, committees, working groups, etc. ${ }^{5}$ On the other hand, functional instruments or processes seek to create or achieve coherent behaviour, policies, etc. They range from rules and standard-setting, budgetary or civil service constraints, strategies and information sharing.

\section{The Exploration of Coordination Structures and Practices in Croatia}

\subsection{Croatian Coordination Issues - A Fine Example of the Problems of Coordination in a Transition Country}

Coordination as administrative function and policy work in transition countries (CEEs and other) has been often addressed in policy documents of international organisations (see OECD 2004, 2007, 2008). The comparative studies аге rare, and focus mostly on core executives (e.g. Dimitrov, Goetz, \& Wollmann, 2006), or, if dealing with structures, are concerned based on comparative or single case research of specific policy coordination. Scientific research on coordination is mostly confined in single case studies or two or three countries comparisons of EU accession coordination structures and EU policy coordination, often from the point of the Europeanisation literature (FinkHafner, 2007; Gärtner, Hörner, \& Obholzer, 2011; Zubek \& Staronova, 2012).

5 As horizontal coordination structures Peters (1998) enumerates at the core government level following structural instruments - chief executive staff, central agencies, cabinet, cabinet committees, ministers without portfolio or with additional coordinative portfolio and junior ministers; at the ministerial level - super ministries, advisory bodies, boards; agencies with portfolios relevant to coordination; interministerial organizations; task forces, working groups and others; interdepartmental committees, coordinating organizations; coordination at the bottom; and informal organizations, such as political party, interest groups and civil service network.

Temmes (2006) leans on Mintzberg's differentiation and conceptualises the structures of coordination as containing strategic apex, which is supporting prime minister as a main tool of governance; techno structure, involved in strategic planning, budget frames, controlling, personnel policies and training, organisational development, etc.); and administrative support as administrative machinery responsible for legal and budget control. 
As an explanatory variable for different adaptations the role of administrative tradition is emphasised, as well as changes in government (Fink-Hafner, 2007). Staronova (2002) argues that the focus should shift from the content of the policies to the way policies are made - their formulation, implementation and evaluation (see also Petak, 2008).

For example, Saner et al. (2008) focus on inter-ministerial policy coordination in government cabinets and its critical role in governance, emphasising the pressure put on developing institutions in CEEs for simultaneously managing complex change and multiple problems. "The large number of tasks ranging in character from simple to complex requires the establishment of sophisticated organisational structures that are able to combine various governmental entities, such as ministries, departments, agencies, commissions, etc. To effectively cope with the activities of all these administrative bodies, ECE/ SEE governments had to develop sound and constructive coordination mechanisms that were expected to result in an effective and efficient decisionmaking process" (ibid., p. 222). The role of EU accession is accentuated as one of the main drivers for administrative change, including coordination structures and processes (ibid.). However, CEEs are facing problems when it comes to effective coordination, because the immanent problems of their administrative and political elites - lack of managerial skills, lack of expertise in leading agencies, lack of civil service ethics and values, politicisation of civil eservice, as well as underdeveloped coordinating structures and inadequate transfer of international models (Temmes, 2006). Part of the explanation might be found in the inherited coordination traditions from previous regime.

Similar conclusions are made in 2004 OECD Sigma paper no. 43 which, in aftermath of Eastern enlargement, deals with CEEs and Western Balkan countries' government offices as "administrative organ that serves the head of the government (usually the Prime minister) and the Government/ Council of minister" under different names (secretariat, chancellery, cabinet office, prime minister's office (OECD, 2004). The study argues that there is a convergence trend in the meaning that CEEs government offices are becoming more similar to the OECD countries' offices in functional terms, but that, at the same time, performance of certain functions in policy spectrum, especially strategic planning and policy-coordination, is still underdeveloped. One of the explanations might be found in the lack of experienced staff which should provide policy advice and support to the political apex of the government. A good indicator that insufficient skills and knowledge decrease the quality of Government offices in CEEs is that "in majority of cases, the Secretary-General (even if he/she is a civil servant) is subject to replacement when Prime Minister changes" (ibid., p. 7).

When it comes to Croatia, a systematic research on coordination in the past two decades is almost non-existent. Except few articles dealing with the policy coordination as well as policy documents on EU accession coordination, there is no scientific or other type of data or analysis which would point out main 
characteristics and problems of coordination. The research devoted to policycoordination within the Croatian institutional context (James \& Staronova, 2003; Petak \& Petek, 2009; Petak, 2015) showed that generally serious limitations do exist in all phases of policy-making process. The ineffective coordination between participants, the role of applying policy analysis tools in the process of formulating a particular policy, and limited capacities for monitoring policy in the phase of implementation may be highlighted as core weaknesses.

Croatian policy coordination system generally suffers from several institutional and structural shortcomings. The prime minister's office lacks a central policy development unit able to evaluate and coordinate the activities of the line ministries. Therefore, the policy expertise of prime minister's office, in terms of policy knowledge of particular policy fields, is strongly limited. Also, gate-keeping role of the cabinet is mostly formal and not based on policy argumentation, or in other words, backed by applicative policy analysis capacity (Petak, 2015). Line ministries consult with the government's legislation office, but this consultation is mostly formal, focusing on technical and drafting issues. Ministries normally enjoy huge leeway in transforming government priorities into legislation, and there is no stable and transparent arbitration scheme that would give the prime minister's office a formal role in resolving inter-ministerial differences. There is a little ex ante coordination among ministries, controversies are often pushed upwards, so that cabinet committees play an important role in reconciling conflicts within the cabinet. And finally, direct coordination of policy proposals by ministries is extremely limited. There is no stable and transparent scheme of settling inter-ministerial differences within the bureaucracy (James \& Staronova, 2003). Deadlines for comments by other ministries are often too short, capacities for comments are sometimes inadequate and comments made by other ministries are often not taken seriously.

Applying the above mentioned policy coordination scale (Metcalfe, 1994; Bouckaert et al., 2010) on the Croatian example, the achievement of higher levels might seem especially problematic, especially levels from six to nine (arbitration, setting parameters, prioritizing, and strategy), which might be related to the inexperience in strategic management. However, the problems do exist also at the lower levels of coordination - in the classical issues of horizontal policy management linked with the consolidation of interorganisational activities. Despite the modest attempt of the Government in 2010 to eliminate the number of agencies (approximately from 78 to 63) by mergers and abolishment of overlapping functions, the concepts like "joined-up government" (Pollitt, 2003) still do not have substantial impact on the course of reform of the state administration in Croatia or the modes of governance in general. Hence, no clear position has yet been taken on how to determine the criteria required for the implementation of a highquality horizontal public policy management - the assessment of the extent 
of overlapping functions, or of the degree of incoherence and of the level of gaps in the policy. A thorough application of policy analysis by adequate expert knowledge is missing. The problem, among others, lies in the supply of policy-related knowledge, in the insufficient number of experts able to carry out policy analysis efficiently.

Another problem is vertical coordination - a reliable institutional mechanism for vertical (as well as horizontal, for that matter) public policy in Croatia is missing, something like the prime minister's or the government's central policy office (Petak, 2008). The overview of institutional practices of vertical policy coordination in developed democracies (ibid.) shows that such a body closely cooperates with the state treasury and all other agencies of central government. Since there is no central government's policy agency in Croatia, the overall authority for carrying out such assessments lies expressly in the hands of the Minister of Finance, who takes part in the work of all coordination bodies and makes decisions on all disputable issues, becoming a kind of a "policy switchman" who acts as a substitute for a central government's policy agency. The problem is in the fact that, this way, decisions are made on the basis of a rough (financial) estimate and not on the basis of a systematic policy analysis.

\subsection{The Research Framework}

The research presented in this paper is focused on the description of the coordination in three distinctive policies in Croatia - the regional development policy, the anti-corruption policy, and the e-government policy. All three policies are new policies which have emerged after 2000 and are to a different degree related to the EU accession. Moreover, all three policies exert features of cross-cutting policies, relating to different sectors. On the other hand, three policies differ in many aspects, such as salience of the policy, type of policy, actors' involvement, mechanisms used for coordination, as well as the role of the EU in the policy development. It has to be noted that The Stabilisation and Association Agreement with the EU was signed in 2001, and the accession negotiations began in 2005. After 2009-2010 crisis, the negotiations ended in 2010, the accession agreement was signed in December 2011 and Croatia became the full EU member on 1 July 2013.

On the basis of the analysis of legal and policy documents as well as the semi-structured interviews with seven public officials, the research focuses on following elements: (1) the key points in the development of the policy (events, actors); (2) the impact of the EU on the policy introduction and formulation and the kind of Europeanisation mechanism used as a main driver of the policy development; (3) the role of international coordination and organisations; (4) who are the main actors involved in the policy formulation and implementation; who are other actors; (5) what kind of coordinating structures emerged and under which circumstances (political and administrative coordination) and who is being coordinated; (6) which 
factors have led to the more elaborated coordination structure. The analysis is focused on the period before the EU membership.

\subsection{The Research Findings - Coordination of Three Policies}

\subsubsection{The Regional Development Policy}

Until early 2000, Croatia's regional development policy did not even exist as a coherent policy framework, since the collapse of socialism and Yugoslavia had resulted in a sort of vacuum ${ }^{6}$, without any ideas what should be the instruments, objectives and goals of the regional development policy (Petak, 2006). What actually did exist in the 1990s was the patchwork of several central governments' activities in the areas of special state concern (related to the heaviest damaged areas in the war 1991-1995), mountain and remote areas and islands (Sumpor \& Starc, 2003). This phase has been described in the literature as the "humanitarian aid stage" (Đulabić \& Manojlović, 2011). The CARDS program in early 2000s was the beginning of the pre-accession process in Croatia, but more recognized regional policy development can be traced from 2005 onwards within the IPA program. ${ }^{7}$

During that period, the regional development policy was continued to be fragmented despite the pressures caused by the EU accession process. The regional policy was still made in a number of ministries (those connected with the economy in general and ministries of regional development, forestry, agriculture, sea, transport, and infrastructure). Moreover, two agency type organisations for regional development were established in 2001 - The Regional Development Fund and The Development and Employment Fund. Legal regulations were equally fragmented since they were applicable to the separate areas of regional development implemented by various sectoral bodies. The missing point was a coherent regulatory framework, which would frame the ways for formulating, implementing and evaluating regional development policy.

A few years after the first discussions on regional development policy had been held, a strategic framework for the 2006-2013 was introduced. It was supposed to become some sort of a template for drafting of all development strategies, including the regional ones. While the document failed to clearly identify the strategic priorities of regional development and was markedly inconsistent and very broad, it was the first time that the term "regional development" was mentioned at all (in the chapter "Space, Nature,

6 Here we should particularly underline the abandoning of the concept of running regional development policy which existed within the socialist system since 1990. The system was created in the final decades of the socialist era and was based on horizontal linking of some one hundred of Croatian municipalities into so-called 'regional associations of municipalities' (Petak, 2006).

7 CARDS Programme (Community Assistance for Reconstruction, Development and Stabilisation) was the EU's main instrument of financial assistance to the Western Balkans, in period 2000-2006. It was replaced by the Instrument for Pre-Accession Assistance (IPA) programme 2007-2013. 
Environment and Regional Development"). However, the change that took place in that period concerned the structured interaction of the horizontal policy actors. With a help from the authorities on the county level, county development agencies gradually started to emerge. They started applying the EU policy narrative used for regional policy, focusing their activities to preparation of specific development strategies on their respective territories. Numerous actors / stakeholders from the economic and civil sector joined the game on the regional level, thus contributing to a gradual shaping up of an institutional context for the regional policy in those years.

A relatively solid regulatory framework for the regional development policy was put in place only in 2009, when the Regional Development Law was adopted, followed by the Regional Development Strategy in 2010. By this token, the institutional core of the Croatian regional development policy was established. The key policy actors in formulating regional development policy in this context included various departments, with a prominent role for Ministry for regional development, but also numerous foreign experts for regional development policy-making, regional/county authorities and regional developmental agencies, as well as, to a certain degree, the researchers from the field of regional development (scholars from the field of economics, social policy, administrative science and public finances). Thanks to the principle of partnership, introduced by the EU regional policy principles, many horizontal policy stakeholders, from the business as well as civil society have been also introduced into the process of developing regional development policy. ${ }^{8}$

What were the basic outcomes of the above mentioned institutional and policy actors' framework? Is regional development policy in Croatia going to become a more coherent and less fragmented policy?

Lack of knowledge by local and regional policy actors related to strategic development goals at the regional level still continued to exist. In other words, the real knowledge of local and county policy stakeholders to discover the ways by which it will be possible to recognize the basic goals, objectives and policy measures which might be beneficial for stimulating regional development left a more or less unrecognized issue. In spite of all efforts devoted to establishing various forms of partnership and partnership forums (partnership at the county level, partnership at the NUTS II level) dissemination of information on how to connect basic policy instruments with particular policy goals and objectives appeared as the basic problem in formulating regional development policy in a specific Croatian case. ${ }^{9}$

8 Policy implementation bodies include Ministry of Regional Development, Agency for Regional Development (established in 2008 with the role of administering regional development funds), partners' council of a statistical region and participation in its work (state administration bodies, regional and local self-government units, private sector, scientific community, social partners and civil society organizations from the territory of the statistical region), regional authority bodies.

9 This kind of remark is sharing much in common with the general findings of Croatian policy scholars related to shortcomings in using ex-ante evaluation techniques in formulating public policy in Croatia (see Petak \& Petek, 2009). 
This kind of observation opens the first issue related to the question of policy coordination in a specific regional development adjective policy. County development agencies (CDA ${ }^{10}$ showed as crucial institutional entities for coordinating policy actors at the regional level, but as the entities with limited success in developing reliable policy coordination required for the effective implementation of local development programs. In interviews made with regional development policy experts in Croatia it has been found that in their judgment a low level disputes in Metcalfe (1994) taxonomy on coordination appeared as a basic problem. Information exchange with other organisations (level 2) and information feedbacks related to limited consultations with other organisations (level 3) appeared to be a basic failure in the behaviour of CDAs. The lack of policy capacities of Croatian CDAs is therefore the first coordination failure issue related to regional development policy.

The other form of policy disputes related to coordination is related to the shortcomings that exist at the departmental level. Namely, there are four basic actors at the ministerial level responsible for implementing IPA III component - Regional development, with three subcategories - transport, environment and regional competiveness. Ministry of Regional Development is responsible for conducting the basic stream of regional development policy, with a special governmental institutions designed in order to formulate and implement such a policy. ${ }^{11}$ Aside from the fact that coordinative mechanisms of regional development policy are located at the Directorate for Regional Development of the Ministry of Regional Development, real jurisdiction over basic components of IPA III is actually allocated to the other three departments - Ministry of Transport and Infrastructure, Ministry of Environment and Ministry of Economy. Croatian scholars in regional policy studies marked previously mentioned overlapping as the basic institutional shortcomings in regional development policy-making, pointing out that it is "quite illogical to have four different managing authorities in charge of almost the same task of managing European funds related to regional development" (Đulabić \& Manojlović, 2011, p. 1054).

Interviews with senior civil servants working in the Ministry of Regional Development showed the inexistence of policy templates for avoiding divergences among ministerial departments, as well as agreements how to conduct joint goals and particularly how to arbitrate in the cases of severe

10 In Croatia 20 developmental agencies were established at the county (županije) level. The only county without its own regional development agency is the City of Zagreb (Zagreb has a dual municipal-county administrative status). The agencies are tremendously different with regard to their administrative and policy capacities, or in other words, the capacity to produce reliable regional projects being able to boost development at the regional level and the capacity to communicate and coordinate actors which indispensable for formulating and implementing regional development policy.

11 Within Ministry a Directorate for Regional Development is established, with a particular Sub-Directorate for Regional Development Policy (the other sub-directorates are related to islands, implementation of developmental programs etc.). The above mentioned subdirectorate is divided into division for Regional Development Policy and Coordination and division for Monitoring and Reporting. 
policy differences (levels 4-6 in Metcalf's taxonomy). This kind of policy disputes can be marked as the second failure in effective policy coordination of regional development policy.

Nevertheless, the current processes of Europeanisation of regional development policy in Croatia showed itself as a more coherent step in comparison to absolutely fragmented policy in that field which did exist before 2000. Vertical and horizontal policy actors (Colebatch, 2004) started to apply the EU policy narratives connected with regional policy, focusing their activities to preparation of specific development strategies on their respective territories. Numerous stakeholders from the business and civil sectors respectively joined developmental policy game on the regional level, thus contributing to gradual shaping up of an institutional context for the regional policy in Croatia in years following 2000.

Almost the entire new framework of the regional development policy came into being as a result of direct pressures from the EU (Bache et al., 2011). The regional development policy was used to harmonize local and regional development needs with the priorities of the central government, ensure support to less developed areas and provide even and sustainable development of local and regional self-government units in border areas. The entire institutional framework, defined by the Regional Development Law - regional development policy, development index, regional development policy planning documents (Croatia's Regional Development Strategy, county development strategies), supported areas, development program plan, statistical region, government programs strategy - is strongly defined by the narrative of the EU Cohesion Policy. The same can be said for the fundamental principles on which the policy was to be based: solidarity, equal opportunities, partnership and cooperation, strategic planning, pooling of resources, monitoring and evaluation (a central electronic database of development projects was established), sustainability, local autonomy. Since the EU had also invested considerable funds into the post-war reconstruction of Croatia, it started indicating that drawing of the resources from the pre-accession funds would not be possible without appropriate paperwork coverage. ${ }^{12}$ That gave a direct boost to the creation of regulative frameworks necessary for running coherent regional policy - Regional Development Law, Regional Development Strategy, county regional development strategies.

\subsubsection{The Anti-Corruption Policy}

The anti-corruption policy (AC policy) is an example of a cross-cutting state administration policy with far reaching political, societal and economic effects. In recent decades the corruption has been recognized as one of the main obstacles for exercise of citizens' rights and the functioning of the state,

12 In accordance with pre-accession activities and for the administrative purposes of EU funds, Croatia has been divided into three NUTS-2 regions: Northwestern Croatia (six counties), Eastern Croatia (eight counties) and Adriatic Croatia (seven counties). 
but also as the problem which undermines both public trust and the economic investments and development (Erakovich, Kavran, \& Wyman, 2006, p. 1238). Corruption relates to the abuse of public authority, most often based on an illicit exchange between a public official and another person, in order to achieve private gain (for typology see Pedersen \& Johansen, 2006; Matei \& Matei, 2010; The World Bank, 2000). The fact is that the corruption is often left undiscovered, it is important to observe not only reported and sanctioned forms of corruption, but also the perception of corruption in the society. ${ }^{13}$

Starting from the fact that the corruption undermines democracy and human rights, as well as the economic development and the functioning of the market, the AC policies have been designed and supported especially by the international organisations. Several important international agreements and documents, such as those of the United Nations, the Council of Europe, especially its anti-corruption body - GRECO, the World Bank, the OECD, as well as the EU, have been adopted during 1990s, the decade of the fight against corruption, and the efforts have continued in the 2000s (see Grubiša, 2010). ${ }^{14}$ In addition, the anti-corruption programmes and activities were advocated by international civil society organisations and think tanks (e.g. Transparency International, etc.).

After the break-up of socialist regimes in CEEs, the corruption problem became immediately evident and continued to endure during the transition phase in the 1990s and later. Within the reform assistance projects, the OECD, the EU and other actors have promoted the two step approach towards the problem of corruption in CEEs: during 1990s, the activities were directed towards the awareness rising, mostly by cooperation of international organisation with the domestic NGOs, and in the 2000s towards capacity building, especially with regard to the inclusion of state and local authorities (Bryane, 2007; Erakovich et al., 2006). The anti-corruption efforts are integral part of the EU enlargement policy and the EU neighbourhood policy (see Börzel \& Pamuk; Matei \& Matei, 2011). The OECD (2008) differs between institutions engaged in prevention and combating corruption, to whom different anticorruption functions are assigned: policy development, research, monitoring and

13 The benchmarking of the countries with regard to the perception of the corruption has become a widespread means to assess the prevalence of the corruption and the quality of government, as it is done by the Corruption Perception Index of the Transparency International or the World Bank's Control of Corruption index. According to the 2011 Corruption Perception Index, Croatia's score was 4.0, the same as in Montenegro and Slovakia, which put them 66th out of 182 countries, better than Italy (3.9), Greece (3.4), or Bulgaria (3.3.). But, when 'perception' is measured, there might be a tendency to score higher in perception at the very beginning of the fight corruption activities, when this issue is interesting for the media and politically important, as stated by one of the interviewers.

14 Examples include the UN Convention against Corruption (2003, also signed by the EU), the GRECO's (Group of States against Corruption, including 48 European states and the USA) Twenty Guiding Principles for the Fight Against Corruption (1997), the OECD's Convention on the Combating Bribery of Foreign Public Officials in International Business Transactions (1997) and later recommendations (2009), the EU's Convention on the fight against corruption involving officials of the European Communities or officials of Member States of the European Union (1997) or European Commission's Communication on a comprehensive EU policy against corruption (2003). 
co-ordination, prevention of corruption in power structures (ethics, access to information, conflict of interest, etc.), education and awareness raising, investigation and prosecution (sanctioning of corruptive behaviour). As one of the main instruments of prevention of corruption, the establishment of independent anti-corruption agencies has been advised by many international organisations, with the main purpose to ensure implementation and coordination of the policy and to disseminate information and knowledge (see Pedersen \& Johannsen, 2006). The OECD study (2008) distinguishes between three types of anticorruption agencies - (1) multi-purpose agencies, (2) law enforcement type institutions and (3) preventive, policy development and co-ordination institutions. One international study has shown that for the ensuring the effective coordination of the AC policy, the setting up of a special body or unit with clear authority, resources, capacity and political support is necessary (see Chêne, 2009).

Similar to other CEE countries, the emergence of the AC policy in Croatia is related to the EU accession - it was introduced after the signing of 2001 Stabilization and Association Agreement, and developed further in the course of negotiations process from 2006 onwards, when anti-corruption measures were defined as a part of the EU acquis (in chapter 23 Justice and human rights and also assessed within the general democracy and the rule of law). The political weight of the AC policy has proven to be one of the most important for the finalization of the accession process. The main goal was to develop effective institutional mechanisms for combating corruption, in other words, specific policy instruments, as well as effective coordination mechanisms and organisational resources. However, the AC policy has undergone three different phases, marked by different structural and functional elements.

The first National Programme for Fighting Corruption with the Action Plan for Fighting Corruption were adopted by the Croatian Parliament in March 2002, but the content of the document and the institutional back-up for the implementation did not indicate the existence of the determination and the political will to fight corruption. The recommendation for the establishment of the National commission for the implementation of the Programme was not put into effect, and one of the reasons was that the parliamentarians were not sure how to define the composition of the Commission. To illustrate, one MP said "I think we are not mature enough to give the presidential seat of the Commission to the opposition politician". The administrative coordination was trusted to a newly established body (2001) - the Office for the fighting corruption and organized crime of the Ministry of the interior, but which did not posess real coordinative powers towards other bodies and organisations entrusted with different measures. In sum, National programme was not "a systematic effort to develop a national policy" and the "political will... was insufficient for its realisation" (Кregar, 2010, p. 7). Consequently, the programme was not implemented. 
The period 2006-2008 marked a new phase in the AC policy development in which institutional framework started to emerge, due to the international and the EU pressures - the international documents were ratified by the Parliament and the EU was stricter on the topic of anti-corruption. Consequently, the new strategic document - the National Programme for Fighting Corruption 2006-2008 was adopted in April 2006, and the monitoring body of the Croatian Parliament was established in October 2006 - National Council for the monitoring of the implementation of the National Programme for Fighting Corruption. The Council was comprised of five MPs and six representatives of various stakeholders - employers, trade unions, civil society, academia, experts and the media, elected on the basis of the public call. ${ }^{15}$ This Program was slightly improved version of the 2002 Program, and in this respect might be considered as a small step forward with regard the anti-corruption efforts, but it also suffered from many shortcomings - the action plan for the implementation was confusing goals and measures, no clear indicators were defined, and no effective coordinating mechanism was envisaged, except the coordinating role of the minister of justice (a national coordinator for the anti-corruption) who was supposed to support and help state administration and other bodies to develop their action plans for anticorruption. The Report of the National Council for the period 2006-2007 expressed the concern about the feasibility of the implementation especially with regard to the capacity of the Council to monitor the implementation, taking into account weak support service which was not capable to analyse the data and reports submitted by various bodies.

The third phase of the AC policy development lasted from 2008 to 2010 when a significantstep forward in the ACstrategy developmentand institution building was made. In July 2008 the Anti-Corruption Strategy, accompanied by the Acton Plan was adopted, with specification of measures, deadlines, resources and responsible institutions. The objective was to design an appropriate institutional framework which would make the combating corruption more effective, based on the fact that the previous programmes lacked effective coordination and cooperation among institutions implementing the policy as well as their efficient supervision. The Action plan referred to various action areas and measures, as well as different organisations included in implementation (state administration, agencies and other legal persons, public enterprises, and local and regional government to a lesser extent). The biggest step was made towards more elaborated institutional set-up the institutional structure included the monitoring body, the coordinating body, and operative level bodies. First, the supervisory and monitoring body of the Croatian Parliament was the National Council for Monitoring the Anti-corruption strategy implementation, supported by the Parliamentary service, to which the different implementation bodies report. The tasks

15 The president of the Council was the head of the minor parliamentary opposition party (not the main opposition party social-democrats), but had the experience in combating organized crime, as a former police officer. 
of the Council included supervision and monitoring of the implementation of the AC Strategy, systematic evaluation of data on corruption practices delivered by implementing bodies, analysis of the reports of implementing bodies, and evaluation of instruments and results; it also proposes measures to increase effectiveness of the implementation of the AC strategy, promotes and directs cooperation between the Parliament, government bodies and other bodies included in the implementation, and submits semi-annual reports to the parliament.

Secondly, the main coordinating body at the executive level the Government was the Commission for the Monitoring of Implementation of the Anticorruption Measures (April 2008), with the task to inter-ministerial cooperation and coordination. The Commission's role was to assess the corruption risks and to propose and define measures for their prevention, to coordinate the implementation of the Strategy and the Action plan, to improve the effectiveness of the AC measures, and to promote cooperation. At the beginning, the Commission's 20 members included the minister of justice as the national coordinator and state secretaries of eleven ministries plus representative of the bodies entrusted with the implementation of the specific activities. The Commission was firstly envisaged as the executive level coordinative body, but its composition changed in 2009 when the new prime minister took over the leading role in the Commission, lowered the number of members to 14 , and instead of the state secretaries nominated the ministers as the members of the Committee and the head of the State Commission for Public Procurement Control. This evolution towards political coordination body indicates the higher level of the political salience of the AC policy, but also might point out towards greater political will to address problem of corruption. Still, in practice, the new composition did not lead to more effective coordination because, as one of the interviewers said, the prime minister did not invest enough energy and time in the Commission tasks. ${ }^{16}$

The support to the Commission and administrative coordination was delegated to the special organisational unit of the Ministry of Justice to serve as the Commission's Secretariat - first as a as an Anti-Corruption Department within the Ministry of Justice Strategic Development Directorate, later as the AntiCorruption Sector of the Ministry of Justice. The ACSector's role was to propose the strategy development and specific anti-corruption measures, to ensure cooperation and coordination among implementing bodies, to collect data and conduct analysis, and to organise educational and promotional activities, including the management of the network of coordinators in implementing bodies. At the operational level, the implementation was entrusted to various

16 The effects of the policy were hardly to be seen by the public and the criticism came also from the European Commission. Although in contrast to service delivery policies the anticorruption policy outcomes were not clearly measurable, still, most of the indicators of the corruption showed that the level was not dropping and the institutions were not sanctioning the cases. It was not until 2010 when the policy has started to realize some effects, having managed to prosecute former prime minister, several ministers and agency heads. In addition, one of the ministers involved in AC policy has been charged of serious corruption scandal. 
bodies, such as specialised AC units of the police and public prosecution and judiciary, horizontal ministries (finance, administration, etc.) and independent bodies in charge for supervising implementation of the access to information, conflict of interest, audits and public procurement legislation.

The next phase in the AC policy development (2010-2012) started at the end of 2009 when the composition of the Commission has changed, as described above. In 2010 the AC policy was revised and the new Action plan was drafted, including a special anti-corruption programme for state owned companies. Although the revision of the policy was supposed to be conducted annually, this was the first time it was reviewed in practice in order to exclude inconsistencies and to introduce some new measures. One of the reasons for the new approach was the change in prime ministerial position in July 2009 and the greater political salience of the corruption issue due to the numerous corruption scandals and prosecutions of highly ranked politicians. On the other hand, the public enterprises were detected as main polygons of corruptive practices, standing outside of effective legal and political control. In addition, two politically driven considerations affected the change. First, the Commission's Accession Reports stated that the AC policy had to be implemented more effectively in order to fulfil the obligations of the EU accession, and this condition became condition sine qua non of the membership. The revision of the Action plan had to take into account the Report of the Commission and GRECO recommendation. Also, the National Council, under the leadership of very enthusiastic opposition politician from March 2008 to end 2011, was eager to steer more effectively and to monitor the AC strategy implementation, addressing specific issues of the policy and opening to the public some of the important corruption cases. As compared to the previous Action Plan, the Revised Action Plan contains a somewhat limited number of measures, but provides for better-defined implementing agencies, action points, objectives and time-frames, although it still lacks clear performance indicators for the implementation of measures.

In sum, what lessons might be drawn from the development of the AC policy in Croatia? First, political importance of the issue gives the policy higher priority and seeks for stronger coordination in order to implement the desired measures. As discussed previously, the political salience of the issue combined with the political pressures from the EU gave impetus to the more complex approach to policy and development of coordination structure which should ensure implementation. In addition, political actors (political entrepreneurs) seeking to advance their political position might influence the working of the existing coordination structures - the new prime minister changed the composition of the Commission (end 2009) and gave it more political weight, while the new president of the Council (2008-2011) significantly improved its working and its monitoring role, constantly putting the issues on the agenda of both Parliament and the general public. As one of the interviewers said, the first Commission was ineffective in the meaning that the representatives 
of the implementing bodies were lower level officials who had no real power to decide or to enforce decisions and the leading role of the minister of justice only confirmed to others that the AC policy is the policy of ministry of justice, and not the cross-cutting policy. Having in mind that the upholding the policy monitoring and coordination to higher political levels gave the policy implementation new speed and steering, the idea of abolishing the Commission seems to be leading the policy into a wrong direction. ${ }^{17}$

Secondly, the crucial factor of the effectiveness of the AC policy formulation and implementation is political backing and the capacity of administrative coordination mechanism (AC agency), especially in terms of the resources and authority to impose measures, as shown by some studies (e.g. OECD, 2008). The department within the ministry of justice, despite all its efforts, does not have any of these prerequisites. In many of organisational shifts it has encountered during these times, the department had insufficient resources, what has been underlined in the European Commission reports, but, what seems more important, it failed to build an image of the independent specialized body which could have resources and authority to coordinate and cooperate with overall public administration and public sector bodies, not even at the level of negative coordination (information gathering and the accessibility of other institutions). This fact, together with low political support, proved to be decisive for the implementation of the policy. Moreover, the administrative coordination gives the policy necessary continuity and the know-how and works as a counterpart of the political changes on the top, which have had a strong effect on the AC policy in Croatia, as interviewees noticed.

Finally, the effect of the EU accession as in many policy areas in CEEs, shown also in previous section, has proven to be decisive for the development of policy. The carrots and sticks approach which forces candidate countries to adopt legislation and establish institutions for the anticorruption policy might be regarded as one of the most important drivers, in addition to domestic political circumstances (Schimmelfennig \& Sedelmeier, 2005). In this case, the problem of asymmetry of power might be considered as positive, since in the absence of the EU pressure the AC policy might develop even slower than it has so far.

In sum, the overall coordination of AC policy in Croatia has gradually improved since first steps have been made in 2002, and some more significant efforts in 2006-2008 and 2008-2012 period. The process shows that coordinating structures have evolved in both political and administrative part, especially after the political upgrading of the governmental coordination committee

17 In 2012, upon expiration of the 2008-2012 Strategy, the AC policy faced obstruction. New Commission members have not been appointed almost a year after new Parliament had been established, and one interviewer said that 'the government is considering abolishing the Commission since it does not see what its role is'. This indicates that the coordination of crosssectoral policy is not seen as being important, and that the political coordination within the party might be given advantage before the formalized and managerial type of coordination on the political and administrative level. 
to ministerial level, directly chaired by the Prime Minister, which has increased the authority of the anti-corruption unit of the Ministry of Justice. The AC policy coordination exhibits features of both hierarchical type of coordination at the political level, and the network type of coordination at the administrative level (the secretariat and the coordinators in implementing bodies). Still, the coordination is not informal nor voluntary, but formal and obligatory, backed up by legal instruments of highest rank. Although the locus of coordination is government Commission, in practice the practical coordination rests upon the secretariat, what makes its capacity and political support even more important. With regard to Metcalfe's typology (1994) besides the forms of negative coordination, the AC policy witnesses the development of more elaborated approach and advanced levels of coordination (7-9 levels, setting priorities and developing the strategy) which is, at the practical level endangered by frequent organisational changes, low organisational capacities, and changes of the strength of political support towards the common goal.

\subsubsection{The E-Government Policy}

The e-government is usually defined as the use of internet to deliver services and information to citizens and businesses. The implementation of e-government projects is expected to create public value with regard to the increased efficiency and effectiveness, greater accountability and transparency, and overall economic and social development. At the service level of public administration, the e-government aims to simplify and make the procedures faster and less expensive and create quality services which are easily accessible. It rests upon the collaboration with the private sector for technological development and infrastructure building. In today's digital economy and society, the public administration reform and policy are inevitably connected with the e-government policy. ${ }^{18}$ In the EU the e-government policy, as a part of information society policy, has started to develop already in the 1990s (Bangeman report, 1994), but its main framework was created on the basis of 2000 Lisbon agenda and the vision of the EU as a knowledge society built on the ICT, as a promoter of employment and economic and social growth. The annual ministerial conferences define goals and measures on the basis of the strategic documents eEurope2005, eGovernment beyond 2005, the Initiative i2010, and the Digital agenda for Europe.

The e-government policy rests upon a coordination of various administrative organisations in order to create unified service to the final user. In other words, the e-government initiatives enable administrators to deliver services focusing on customers, tailored to their needs, regardless of vertical and horizontal fragmentation of policies included (P. 6, 2004). One-stop shop initiatives, e-government portals, and integrated services in general

18 Similar to the AC policy, the e-government is a good example of policy the results of which are subjected to the benchmarking as a means of achieving continuous improvement (the UN e-government rankings, eParticipation index, the Economist's e-government readiness index, etc.). 
are actually based on the coordination behind the screen, simultaneously facing public administration with managerial, legal, financial and democratic (accountability) challenges. When it comes to the coordination functions within e-government policy, it relates to the developing of (a) information infrastructures and one-stop shop centres, (b) formulating legal framework for e-government and information technology, (c) mobilising, prioritising and allocating resources for infrastructure and services and (d) monitoring, evaluating and communicating information, experience and ensuring accountability (Hanna et al., 2009). For that purpose, the coordinating institutions, their position in wider governance structure, political weight and administrative capacity are of utmost importance for the success of the policy. ${ }^{19}$

As in many other countries, the e-government policy in Croatia started to develop as part of information society policy, and later became the integral part of public administration reform policy. ${ }^{20}$ The development of the information society and e-government policy might be traced back into the period of the left-wing coalition government 2000-2003, although some sporadic efforts were made already in the 1990s. ${ }^{21}$ Within the framework of the Strategy - Croatia in 21 century, a first Strategy on Information and Communication Technology was adopted by the Government in 2002, as a program document, containing only 17 recommendations which had to be further developed by implementation bodies (within several projects - state administration, business, culture, international relations, housing, health and environmental protection). Specific e-government related activities were not exceptionally prominent within the strategy, because the priorities were related to the general informatisation and the development of the legal framework related to the use of the ICT and overall dedication to the inclusion of Croatia in the EU. The institutional framework envisaged by the Strategy included the National Council for Information Society Technology and the Parliamentary Committee for Information Society Technology as monitoring bodies, the coordination by the Commission for Informatisation (political coordination), and shared coordination by the Government Office For Internalisation (established in 2000) and the Ministry of Science and Technology. At the operative level, the activities are implemented by ministries and specialized agencies.

19 Hanna et al. (2009) distinguish between four models of e-government institutions - policy and investment coordination, where a cross-cutting ministry has the lead of the e-government policy (Australia, UK, US, Brazil, China), administrative coordination, where ministry of public administration or similar is in charge (Germany, Slovenia, Bulgaria, Mexico, Korea), technical coordination, where the ministry of science, technology or similar leads the policy (e.g. Romania, India, Singapore), and shared or no coordination (Sweden,. Russia).

20 As a result of the implementation of e-government policy, Croatia ranked 30 th in the UN e-government survey 2012, see: http://www2.unpan.org/egovkb/

21 During 1991-1996 the institutional framework included the Institute for informatisation of state administration, justice and public affairs within the Ministry of justice and administration and the Government Commission for the informatisation of state administration, justice and public affairs, as coordinating bodies. 
The next stage of the development of e-government policy relates to the period 2003-2007 and 2008-2011. As one of the key policies of the new government the main strategic document for the development of information society in Croatia was adopted in 2003 under the title Programme e-Croatia 2007 (for the period 2004-2007), accompanied by the Plan of implementation of the Programme 2007, which defined specific measures for implementation and the implementation and monitoring mechanism. It encompassed various projects and activities, focusing of four areas: e-government, e-judiciary, e-education and e-business. ${ }^{22}$ In addition, a specific strategy of the one stop shop was adopted in 2004 (Hitro.hr), focusing on the development of e-services on both central and regional level. The specific Strategy of E-Government was adopted in 2009 for the period 2009-2012, with the main goal to develop customer-oriented, accessible, accountable and efficient administration. The priorities related to the user satisfaction, rational administrative procedures and e-services provision. The Strategy focused on the informatisation of state administration and its service orientation towards users based on the development of ICT infrastructure in the state administration, informational basis, e-service accessibility and the development of human resources in the area of e-services provision. As main activities, the Strategy emphasised the interoperability framework development for the public sector and the interconnectedness of the state administration bodies, the development of the information portal, the e-office project (file management), and similar.

The main coordinating body in the period 2004-2011 was the Central State Office for E-Croatia (CSOEC), ${ }^{23}$ a semi-autonomous agency headed by the politically appointed state secretary and directly accountable to the Prime Minister. The main tasks of the CSOEC were the coordination and implementation of the Programme e-Croatia 2007 and coordination of the interoperability scheme for the state administration bodies, monitoring the implementation of the EU acquis with regard to information society, and advancement of the development of information infrastructure in Croatia. The CSOEC was an integrator and a coordinator of the network of coordinators for Programme implementation in state administration bodies and agencies. Based on the Strategy of E-government and the Croatian Interoperability Framework, the Council for Informatisation of State Administration was established in order to define and monitor the implementation of the Croatian interoperability framework, comprised of the state secretary of the CSOEC and the representatives of state administration bodies. In addition, as the advisory and monitoring body of the Government, The National Council for The Information Society was established in September 2004,

22 Within the Programme, various projects were envisaged, such as e-treasury, e-public procurement, e-customs, e-taxes, e-court decisions, e-land register, e-information boards of the courts, integrated information system of judicial files management, e-education, and e-health.

23 From 2004 onwards the new type of administrative organisation closely linked to the government was established - central state office (later only state office) for managing horizontal tasks, such as e-government policy, public administration policy, strategic development policy, and the state property management. 
and its 14 members (representatives of the state bodies and of private sector, civil sector and academia) were appointed two years later (April 2006). The Council was headed by the State secretary of the State Office for E-Croatia (SOEC). The role of the National council was to analyse and define directions of the information society development, and to enforce implementation of the priority goals and measures.

At the operative level, the main bodies, except state administration bodies (ministries, state administrative organisations, agencies), include agencies implementing information society policy, such as Agency for Information Systems, Agency for Personal Data Protection, Agency for Electronic Communication. The implementation bodies were obliged to submit their monthly report to the CSOEC which then drafted the yearly report and submitted it to the Government.

In 2012 the e-government policy entered a new stage, with the Government coming into power at the end of 2011. In February 2012 the Government established the Commission for Coordination of Informatisation of Public Sector, a political level coordination body, comprised of the two deputy prime ministers, seven ministers and the assistant minister in charge for informatisation of public sector within the ministry of administration. The Commission has five working groups for administrative level coordination of various areas of informatisation of public sector (for registers, for electronic identity, for public procurement, etc.), comprised of the representatives of state administration bodies and agencies in the field of information society. The support to the Commission and the working groups is provided by the Ministry of Administration, which is now in charge of the activities of the former CSCOE which was abolished in March 2012 and became a Directorate for e-Croatia of the Ministry of Administration, with more elaborated scope of affairs, but mainly keeping its policy development and coordinative function. The newly established working groups, comprised of the civil servants, private sector representatives are expected to develop specific strategies and later coordinate their implementation, under the umbrella Commission.

In sum, higher political salience of the e-government policy was motivated by the need to make public administration more effective and less expensive in the situation of economic and financial crisis. As indicated by interviewees, the implementation of the informatisation projects in public administration was not successful, the interoperability was not achieved, and the citizens and business still do not feel significant benefits of the informatisation of administration and the information society in general. Although a progress in the development of e-government and information society in general has been made in previous decade, some problems remain, mostly related to the highly fragmented state and public administration and the fact that the projects are expensive and complex. As one of the interviewees noticed, the implementation of previous strategies and projects was hampered by the fact that the former CSOEC was politically weak in comparison to might ministries 
and their ministers who were reluctant to give the Office the leading role. The other interviewee noticed that the National Council for Informatisation of State Administration (established in 2010) was also inefficient due to the low political weight - the state secretaries (a level below minister) were too weak to impose the implementation of the measures to the ministries - "it is not possible to connect islands with the sea". In addition, the monitoring mechanism was not functioning either, since the National Council for Information Society established in 2004 had its last session in 2007, and did not bother to supervise and to steer the policy. Hence, it might be noticed that the e-government policy was not properly coordinated nor monitored at the political level. The politically stronger composition of the new Commission might be a solution since such composition could give more political weight to the issue.

In addition, administrative coordination also encountered problems. First, no joint budget for informatisation of public administration existed, but each administrative body had its own budget for informatisation, which actually lead to the creation of their own agendas (and spending). The problem of implementation might be seen at the operative level too, as some bodies did not see the point in putting information and documents in a speedy manner on the web portals, disregarding their obligations. Moreover, the weakness of the strategic management once again resulted with implementation problems - strategies lacked clear indicators of the success which could define desired results. Although the number of civil servants included in administrative coordinating body (CSOEC, now the Directorate) has continuously grown (to 31 employees), the longer period it had insufficient human resources (10-15 employees). The interviewees assess the collaboration with other state agencies and the private sector (Croatian Employers Union, private sector associations, individual companies) as being good, but mostly due to their professional and expert exchange and mutual dependence and respect, and not due to the greater activity of coordinating bodies. They underline that the strategies and the operative plans were developed in the partnership with the stakeholders (state administration, agencies, private sector, civil sector, academia and experts). Still, local governments were not sufficiently involved in the coordination activities, although they provide a substantial number of services, and their exclusion resulted in bigger cities and counties developing their own e-government policies (often with the help of the CSOEC).

Finally, the impact of the EU e-government policy and the EU accession on the development of the e-government policy in Croatia has been visible from the beginning of the policy development. Already the first strategy in 2002, and especially the Programme 2007 and their presentation in the media and political bodies were framed around two key issues - EU membership and the adoption of the EU information society policy in line with Lisbon agenda 2000, but also the anti-corruption effect of the use of ICT for the provision of public services. Although the measures for implementation of the strategy follow 
the EU policy, the low effectiveness in implementation is due to the fact that e-government policy does not constitute the hard-law acquis which has to be implemented by the coercive means (negotiations chapters cover mostly electronic communication policy and some aspects of the legal framework for information society, such as electronic signature, electronic business, and similar), but, as a policy of negative integration, is based on the open method of coordination and the efforts of the countries themselves to ensure continuous improvement and make efforts to achieve desired goals (benchmarking of e-government serves as a tool for that). Still, the administrative coordinating body is involved in the EU coordination of e-government policy, such as the E-government high level group of the European Commission which is in charge of the implementation of the European action plan for e-government 2011-2012.

\subsection{Discussion}

As presented by the description of the three policies - the regional development policy, the anti-corruption policy, and the e-government policy - are new policies which emerged after 2000 and are to a different degree related to the EU accession. On the other hand, three policies differ in many aspects, such as salience of the policy, type of policy, actors' involvement, mechanisms used for coordination, the role of the EU in the policy development. However, the three policies were formulated and implemented in the politico-administrative system of the transition country where the mixture of the inherited traits of the systems and the newly introduced structures and functions have led to the specific outcomes of the coordination mechanisms and policy outputs. As presented in table 1, comments differences and similarities might be summed up as follows:

The regional policy is a part of economic policy, mostly vertically coordinated, while anti-corruption and e-government policy are cross-cutting policies predominately based on horizontal coordination of state level actors. The direction of coordination (vertical vs. horizontal) and the fact that political forces behind different levels (national, subnational) are pursuing their distinctive political (and economic) interest, have determined the process of policy formulation and implementation. While in the regional policy the most powerful actors are subnational and private sector actors, who have the greatest capacity to influence the outcomes, in the anticorruption policy, the civil society organisations, with the help of the external donors, were pressuring the creation of the policy. When it comes to e-government policy, the private sector actors were included in the policy development, having special interest in collaborating with the government in the ICT solutions development, but also as the users of government services, pressuring for faster and more effective administration. In all three cases the role of domestic experts (academia, consultants) was high, especially in the policy formulation stage, since government lacked their own expertise. 
With regard to the influence of the EU and the Europeanisation mechanism, all three policies are actually "European" policies, ${ }^{24}$ introduced after the 2000 and developed in at least two distinctive stages - the first attempts to introduce the policy and coordination mechanisms were modestly successful, suffering from the beginner's mistakes, with weak institutional framework, undeveloped strategies and questionable political support. After the beginning of the EU membership negotiations, a more advanced policy was developed, but still with the shortcomings with regard the strategic management, which is a generally underdeveloped administrative function in Croatia, as well as the modestly successful coordination mechanism. The type of Europeanisation (Schimmelfennig \& Sedelmeier, 2005) ${ }^{25}$ in three policies is different - the regional policy is part of the formal acquis communautaire and its content is strongly influenced by the EU law; so, the mode of adoption relates to the coercive type of Europeanisation where the fulfilment of requirements from the negotiation chapter 10 is a prerequisite for the further advancement in the negotiation process (external incentives model with legal requirements). The anti-corruption policy of Europeanisation also rests upon coercive mechanism, but the instruments are more political - only smaller part of the policy is based on the formal acquis, and the rests is a matter of political evaluation of the progress (external incentives model with political requirements). Still, the difference between two types of external incentives led to the different focus of the assessment - in the regional policy it is an adoption of formal mechanism, which does not guarantee the desired outcome of the policy (shallow or formal Europeanisation), while in the case of the anti-corruption policy, except legally defined framework, the policy outcomes were assessed based on the sanctioning and criminal procedures. Finally, the e-government policy is a policy which is designed by the means of the open method of coordination, and the Europeanisation mechanism rests upon the combination of social learning (normative type), and lesson drawing (mimetic type of adoption of the policy). Since the results are hard to measure (and not immediate) and the benchmarking suffers from its own methodological problems, the general assessment of the policy success is not

24 It is almost impossible to analyse any public policy in Croatia in the last decade without inclusion of the factor of the EU and its political, legal and/or financial support.

25 Schimmelfennig and Sedelemeier (2005) presents three mechanisms of Europeanisation in CEEs, depending on the source of change (EU or domestic level) and the contrasting logics of consequence (RCI) or logic of appropriateness (SI): (a) the external incentives model, based on the logic of consequence, when sanctions and rewards are affecting cost-benefit calculations of candidate countries; the carrot and stick models achieves greater explanatory power with the increase of net-benefits of accession and with credibility of the EU; it is based on conditionality - the advancement in the accession process is connected to the speed and pace of institutional adjustments and reforms conducted by the prospective member); (b) the social learning model - the change is induced by the learning process - the legitimacy of EU norms and identification with the EU is a factor for adaptation; this process is developed through intergovernmental interactions (negotiations, persuasion) or through transnational processes which gather societal actors (interest groups, regional authorities); finally (c) the lesson-drawing model explains change by national level causes - unsatisfied with domestic status quo, the states adopt the EU rules if they are perceived as solution for their domestic problems, according to the logic of consequence, or their appropriateness for institutional adjustment. The prevailing mode of institutional change in CEEs is explained by external incentive model, in other words, by "reinforcement by reward". 
simple. Still, the content of the policy and the support in policy formulation and implementation is in all three cases connected to the efforts of the European Commission, but in the case of anti-corruption policy other actors and formal obligations also play significant role (Council of Europe, Un, OECD, World Bank), while in the case of e-government the role of international benchmarking and participation in the UN has an impact on the policy development.

With regard to the coordination structures and mechanisms, in all three policies strategies were adopted, first as general statement or programmatic documents, and later in more elaborated versions, but still lacking clear measures and indicators. The reluctance to develop strategies which would enable proper coordination might indicate not only low expertise but also unwillingness of politics to show genuine interest in the success of the policy formulation and implementation. Hence, although the policy coordination scale would say that the strategy is the higher level of coordination, the Croatian case shows that even with the strategy, the coordination may be insufficient. It also points towards low strategic capacity of institutions, and certain misinterpretation of the role of strategy. It is commonly understood in Croatia that the strategy relates to the document containing priorities and instruments for reaching certain policy goals, but this notion without exception excludes a proper establishment of proper organisational structures and resources (financial, skills) to implement, monitor and report on strategy. Hence, although formally one could say that three policies have reached the highest levels of policy coordination, in reality it is not a case.

Main coordinating structure at the political level underwent constant changes - with regard to the regional policy, it was frequently changing organisational frame (different ministries), the anti-corruption policy was coordinated by ineffective commission, which was later upheld to higher political level, while the e-government in past really had no political coordination, except the symbolic one, in the person of prime minister. In 2012 the political coordination of regional and e-government policy became stronger, with a greater political salience of these issues, due to economic crisis - the regional policy is now (2012) situated in the special Ministry of regional development, with the minister being at the same time a vice prime minister, while e-government policy was transferred to the Ministry of administration and the coordinated by the government Commission for informatisation, composed by ministers. On the other hand, the anti-corruption policy, now that the accession agreement has been signed, is still in search of political coordination, and the fact that a great number of criminal cases are pending before Croatian courts, might indicate that the public believes that the policy is successful and the political relevance of the issue has decreased. As the experience of three policies shows, the greater political salience of the issue (to the extent that it becomes the problem number one in the political system) leads to the creation of political coordination structure. The public perception of 
the problem plays a crucial role, and the public sees the sanctioning, and not the prevention mechanisms. In other words, the public visibility also pushes towards greater political steering, although in practice the political steering might not be always effective.

Table 1: Coordination of three policies in Croatia

\begin{tabular}{|c|c|c|c|}
\hline & $\begin{array}{l}\text { Regional development } \\
\text { policy }\end{array}$ & Anti-corruption policy & E-government policy \\
\hline policy sector & $\begin{array}{l}\text { economic policy - } \\
\text { regional development } \\
\text { (sector policy) }\end{array}$ & cross-cutting / wicked & cross-cutting \\
\hline $\begin{array}{l}\text { direction of } \\
\text { coordination }\end{array}$ & vertical and horizontal & horizontal & horizontal \\
\hline $\begin{array}{l}\text { the role of other } \\
\text { actors in policy } \\
\text { formulation and } \\
\text { implementation }\end{array}$ & $\begin{array}{l}\text { subnational - high } \\
\text { private sector - high } \\
\text { civil sector - low } \\
\text { experts - moderate }\end{array}$ & $\begin{array}{l}\text { subnational - low } \\
\text { private sector - low } \\
\text { civil society - high } \\
\text { experts - moderate }\end{array}$ & $\begin{array}{l}\text { subnational - low } \\
\text { private sector - high } \\
\text { civil society - low } \\
\text { experts - high }\end{array}$ \\
\hline $\begin{array}{l}\text { the introduction of } \\
\text { the policy / new policy }\end{array}$ & $2001 / 2006$ & $2002 / 2006$ & $2002 / 2008$ \\
\hline The EU impact & $\begin{array}{l}\text { EU chapter } 10 \text { Regional } \\
\text { policy } \\
\text { acquis }\end{array}$ & $\begin{array}{l}\text { democratic institutions } \\
\text { and the rule of law EU } \\
\text { chapter } 23 \text { / political } \\
\text { impact }\end{array}$ & $\begin{array}{l}\text { EU chapter } 22 \\
\text { Information society }\end{array}$ \\
\hline $\begin{array}{l}\text { type of } \\
\text { Europeanisation }\end{array}$ & $\begin{array}{l}\text { external incentives } \\
\text { model / formal }\end{array}$ & $\begin{array}{l}\text { external incentives } \\
\text { model / political }\end{array}$ & $\begin{array}{l}\text { social learning / lesson } \\
\text { drawing }\end{array}$ \\
\hline external actor & $\begin{array}{l}\text { EU - European } \\
\text { commission }\end{array}$ & $\begin{array}{l}\text { EU European commission } \\
\text { Council of Europe - } \\
\text { GRECO } \\
\text { OECD, The World Bank }\end{array}$ & $\begin{array}{l}\text { European commission / } \\
\text { EU information society } \\
\text { policy (OMC) } \\
\text { UN \& other global } \\
\text { benchmarking }\end{array}$ \\
\hline strategic documents & $\begin{array}{l}\text { Strategy 2009, Regional } \\
\text { Development Law } 2010\end{array}$ & $\begin{array}{l}\text { National programme } \\
2002 \text { and } 2006 \\
\text { Strategy and action plan } \\
2008 \text { / revision } 2010\end{array}$ & $\begin{array}{l}\text { Strategy 2002/ Strategy } \\
2009\end{array}$ \\
\hline $\begin{array}{l}\text { main coordinating } \\
\text { structure - political } \\
\text { level }\end{array}$ & $\begin{array}{l}\text { Government / different } \\
\text { ministries, Ministry of } \\
\text { regional development }\end{array}$ & $\begin{array}{l}\text { Commission for AC } \\
\text { strategy implementation } \\
\text { (Government level) }\end{array}$ & $\begin{array}{l}\text { Commission for } \\
\text { informatisation } \\
\text { of administration } \\
\text { (Government level) }\end{array}$ \\
\hline $\begin{array}{l}\text { main structure - } \\
\text { administrative level }\end{array}$ & $\begin{array}{l}\text { different ministries, } \\
\text { Ministry of regional } \\
\text { development/Agency } \\
\text { for regional development } \\
\text { / regional development } \\
\text { agencies }\end{array}$ & $\begin{array}{l}\text { Ministry of justice } \\
\text { - Sector for Anti- } \\
\text { corruption }\end{array}$ & $\begin{array}{l}\text { Central state office for } \\
\text { e-Croatia (2004-2011) } \\
\text { Ministry of } \\
\text { administration - } \\
\text { Directorate for } \\
\text { e-government (2012-) }\end{array}$ \\
\hline $\begin{array}{l}\text { coordinated } \\
\text { actors (policy } \\
\text { implementation) }\end{array}$ & $\begin{array}{l}\text { state administration, } \\
\text { agencies, regions, local } \\
\text { units, private sector } \\
\text { organisations }\end{array}$ & $\begin{array}{l}\text { state administration } \\
\text { bodies, agencies, private } \\
\text { sector organisations }\end{array}$ & $\begin{array}{l}\text { state administration, } \\
\text { agencies, public } \\
\text { institutions (education, } \\
\text { health, etc.) }\end{array}$ \\
\hline $\begin{array}{l}\text { the role of top civil } \\
\text { servants }\end{array}$ & high & moderate & high \\
\hline
\end{tabular}

The main coordinating structure at the administrative level in all three cases shows that the problem of capacity of the organisation and its formal authority to impose obligations to other coordinated organisations is of critical importance for the success of the policy. The great number of involved actors and their different interests and modus of operation impose even greater pressure to coordination than in traditional functional sectors, such as health, education, or similar, where the professionalization may serve as powerful coordinative instrument. As shown by the case of anti-corruption policy, the low capacity and the unsatisfactory position of the organisation 
in the system prevented the agency to fulfil its role - both information gathering and the relations with political masters has suffered. On the other hand, the regional policy administrative coordination depends on the collaboration of central and regional administrative organisations, which, in turn, is defined by political interest. But, most evident case of the importance of the locus and the capacity of administrative coordination is the case of e-government policy, where the state office had problems to impose measures to the ministries since the office itself had the lower organisational position compared to the ministries. ${ }^{26}$ Hence, the combination of proper political support and coordination and the sufficient capacity (resources, authorities) of the administrative coordination is a prerequisite for effective coordination.

\section{Conclusion and Future Research}

In the paper the development of policy strategy and coordination mechanisms was presented in case of three policies in Croatia. All three policies are new, crosscutting, and affected by the process of Europeanisation. The cases presented indicate that the Croatian political and administrative system suffers from inefficiencies when it comes to both strategy development and the establishment of coordination structures which are responsible to implement coordinative instruments. This fact might be explained by the several factors: first, there is a lack of know-how and professional civil service which would be able to devise such instruments and to influence politicians into taking their advice seriously; in all three policies, the state depends on the inclusion of experts in the strategy drafting because of the lack of their own capacities (low professionalism); secondly, there is a problem for politicians and civil servants to understand the role of coordination and to overcome their habits of doing things independently; the spirit of cooperation is missing, indicating a cultural problem (low trust); thirdly, there is still vivid inherited tradition of creating strategic directions and coordinating the policy from the political party, and not within the formal and transparent mechanism of political and administrative coordination indicating a problem of administrative culture and the maturity of democracy; thirdly, the strong incentive from the EU to develop and implement policy might have led to the reluctance and misunderstanding of the importance of those policies for economic and social development which implies a shallow Europeanisation; as many other EU-initiatives, those policies were also seen by politicians, civil servants, and in the greater part of the public as something "we have to do in order to become a EU member" (one interviewee said). Still, in all three cases, the greater advancement in the policy formulation and implementation was a result of greater political pressure from the EU and stronger domestic political support. In all three cases, the administrative coordinating structures

26 It is the same with the public administration - the central state office was in charge of public administration in the period 2004-2009, and in 2009 it was reorganized into special ministry, becoming more relevant politically. 
were slowly built, usually under-staffed, with no resources, political backing and without clear lines of authority and responsibility.

With regard to the levels of policy coordination (Metcalfe, 1994), the research indicates that the policy coordination instruments highly depend on the capacity of administrative structures in charge for coordination, as well as the political support to the strategy and priorities. Sufficiently strong coordinative structures allow for coordinating instruments to be effective, hence ensuring the policy goals attainment. In addition, the proper implementation of those instruments is a necessary prerequisite for coordination - conflict management (5 and 4), information gathering and exchange (3 and 2), and especially strategic management (7-9) are administrative functions which need properly skilled professionals as well as the institutionalisation of these techniques in the system. So far, they are still new and often misunderstood.

The presented analysis of three policies is a first part of the more comprehensive research where the more in-depth exploration of the coordination practices is planned, based on the qualitative and the quantitative research. The focus of the research would cover additional policies (public administration reform policy, anti-discrimination policy, regulatory reform policy), based on more elaborated theoretical framework. This study is one of rare attempts to grasp the coordination problem in Croatian public administration, since no comprehensive, or even more elaborated case studies, have been done so far.

Anamarija Musa, PhD, is assistant professor of administrative science at the Law Faculty of the University of Zagreb, where she lectures on public administration. Her main research areas focus on public administration reform, agencies and coordination, regulation, e-government and transparency, and Europeanisation of public administration. She received her PhD in administrative law and public administration from the University of Zagreb in 2009 and MSc in European Politics and Governance from LSE in 2004. She is a member of IPSA Research Committee 27 on Structure of Government. She is currently serving as the Information Commissioner of the Republic of Croatia, for a 5 year mandate.

Zdravko Petak, PhD, is professor of political science at the Faculty of Political science, University of Zagreb, where he lectures on public policy and political economy. His main research areas focus on the politics of decentralization, political economy of federalism, party funding and campaign spending, governance and horizontal policy management, and the Europeanisation of public policy. He received his PhD in political science from the University of Zagreb in 1999, and held in 2002-2003 a post-doctoral position in comparative institutional analysis and design at the University of Indiana, Bloomington. He was a president of the Croatian Political Science Association from 1999 to 2002 and is currently a member of the IPSA Research Committee 32 on Public Policy and Administration. 


\section{References}

6, P. (2004). Joined-Up Government in the Western World in Comparative Perspective: A Preliminary Literature Review and Exploration. Journal of Public Administration Research and Theory, 14(1), 103-138.

DOI: $10.1093 /$ jopart/muh006

Bache, I., et al. (2011). Europeanization and multi-level governance in South-East Europe: the domestic impact of EU cohesion policy and pre-accession aid. Journal of European Public Policy, 18(1), 122-141.

DOI: $10.1080 / 13501763.2011 .520884$

Beuselinck, E., Verhoest, K., \& Bouckaert, G. (2006). Reforms of central government coordination in OECD-countries: culture as counterforce for crossnational unifying processes? In: K. Schedler \& I. Proeller (Eds.), Cultural aspects of public management reforms. Amsterdam: Elsevier.

Bogdanor, V. (Ed.). (2005). Joined-Up Government. London, Oxford, UK: The British Academy, OUP. DOI: 10.5871/bacad/9780197263334.001.0001

Börzel, T. A., \& Pamuk, Y. (2012). Pathologies of Europeanization: fighting corruption in the Southern Caucasus. West European Politics, 35(1), 79-97. DOI: $10.1080 / 01402382.2012 .631315$

Bryane, M. (2007). The Rise and fall of the anti-corruption industry: towards second generation of anti-corruption reforms in Central and Eastern Europe. Conference on public integrity and anticorruption in public service, Bucharest, 29-30 May 2007.

Bouckaert, G., Peters, B. G., \& Verhoest, K. (2010). The Coordination of Public Sector Organisations. Shifting Patterns of Public Management. Basingstogke: Palgrave Macmillan. DOI: 10.1057/9780230275256

Chêne, M. (2009). Coordination Mechanisms for Anti-Corruption Institutions. U4 Expert Answers, Anticorruption Resource Centre, Transparency International \& Chr. Michelsen Institute. Retrieved 15. 2. 2015, from http://www.u4.no/ publications/coordination-mechanisms-of-anti-corruption-institutions/

Christensen, T., \& Laegreid, P. (Eds.). (2006). Autonomy and Regulation: Coping with Agencies in the Modern State. Cheltenham: Edward Elgar.

Christensen, T., \& Laegreid, P. (Eds.). (2007). Transcending New Public Management: The Transformation of Public Sector Reforms. Aldershot: Ashgate.

Colebatch, H. K. (2009). Policy. Maidenhead: Open University Press.

Davies, J. (2009). The Limits of Joined-Up Government: Towards a Political Analysis. Public Administration, 87(1), 80-96.

DOI: $10.1111 / \mathrm{j} .1467-9299.2008 .01740 . x$

Davis, G. (1998). Carving out Policy Space for State Government in a Federation: The Role of Coordination. The Journal of Federalism, 28(4), 147-164. DOI: 10.1093/oxfordjournals.pubjof.a029992

Dimitrov, V., Goetz, K., \& Wollmann, H. (2006). Governing after Communism. Institutions and Policy Making. Lanham MD: Rowman \& Littlefield.

Đulabić, V., \& Manojlović, R. (2011). Administrative Aspects of Regional and Cohesion Policy in Croatia: In Search of a Better Coordination of Parallel Process. Hrvatska i komparativna javna uprava /Croatian and Comparative Public Administration, 11(4), 1041-1047. 
Erakovich, R., Kavran, D., \& Wyman, S. M. (2006). A Normative Approach to Ethics Training in Central and Eastern Europe. International Journal of Public Administration, 29(13), 1229-1257. DOI: 10.1080/01900690600928060

Fink-Hafner, D. (2007). Europeanization in Managing EU Affairs: Between Divergence and Convergence, A Comparative Study of Estonia, Hungary and Slovenia. Public Administration, 85(3), 805-828. DOI: 10.1111/j.14679299.2007.00668.x

Gärtner, L., Hörner, J., \& Obholzer, L. (2011). National Coordination of EU Policy: A Comparative Study of the Twelve "New" Member States. Journal of Contemporary European Research, 7(1), 77-100.

Gregory, B. (2006). Theoretical faith and practical works: de-autonomizing and joining-up in the New Zealand state sector. In: T. Christensen \& P. Laegreid (Eds.), Autonomy and Regulation: Coping with Agencies in the Modern State. Cheltenham: Edward Elgar.

Grubiša, D. (2010). Anti-corruption policy in Croatia: benchmark for the EU accession. Croatian Political Science Review, 47(5), 69-95.

Hanna, N. K., et al. (2009). National e-government institutions: functions, models and trends. Retrieved 15. 2. 2015, from http://siteresources.worldbank.org/ EXTIC4D/Resources/5870635-1242066347456/IC4D_2009_Chapter6.pdf

Halligan, J. (2006). The Reassertion of the Centre in a First Generation NPM System. In: T. Christensen \& P. Laegreid (Eds.), Autonomy and Regulation: Coping with Agencies in the Modern State. Cheltenham: Edward Elgar.

Hood, C. (1991). A public management for all seasons? Public Administration, 69(1), 3-19. DOI: 10.1111/j.1467-9299.1991.tb00779.x

Hood, C. (2005). The Idea of Joined-Up Government: A Historical Perspective. In V. Bogdanor (Ed.), Joined-Up Government. Oxford: OUP. DOI: $10.5871 / \mathrm{bacad} / 9780197263334.003 .0002$

Hood, C., James O., Peters, B. G., \& Scott, C. (2004). Controlling Modern Government: Variety, Commonality and Change. Cheltenham: Edward Elgar. DOI: $10.4337 / 9781845423599$

Hopkins, M., Couture, C., \& Moore, E. (2001). Moving from the Heroic to the Everyday: Lessons Learned from Leading Horizontal Projects. Ottawa: Canadian Centre for Management Development.

Hustedt, T., \& Tiessen, J. (2006). Central Government Coordination in Denmark, Germany and Sweden: An Institutional Policy Perspective. Universität Potsdam Forschungspapiere Regierungsorganisation in Westeuropa, Heft 2.

James, S., \& Staronova, K. (2003). Review of the central authorities for policymaking and coordination of the Republic of Croatia. Internal report for the World Bank.

Jordan, A., \& Schout, A. (2006). The Coordination of the European Union. Exploring the Capacities of Networked Governance. Oxford: OUP. DOI: 10.1093/acprof:oso/9780199286959.001.0001

Keast, R., Mandell, M. P., Brown, K. A., \& Woolcock, G. (2004). Network Structures: Working Differently and Changing Expectations. Public Administration Review, 64(3), 363-371. DOI: 10.1111/j.1540-6210.2004.00380.x

Koprić, I. (2009). Contemporary Croatian public administration on the reform waves. Paper for the IPSA XXI World Congress of Political Science: Global Discontent? Dilemmas of Change, Santiago de Chile, 12-16 July 2009. 
Kregar, J. (2010). Corruption: Ignorance Is not Innocence. In: J. Kregar, D. Sekulić \& Ž. Šporer, Corruption and Trust. Zagreb: Centar za demokraciju i pravo Miko Tripalo, Pravni fakultet u Zagrebu.

Matei, A. I., \& Dogaru, T.-C. (2013). Coordination of Public Policies in Romania. An Empirical Analysis. Procedia - Social and Behavioral Sciences, 81, 65-71. DOI: $10.1016 /$ j.sbspro.2013.06.389

Matei, A. I., \& Matei, L. (2010). Integrating Anti-Corruption Strategies within the Government Reforms in Some South-Eastern European States: An Empirical Study on the Impact of the Government Performance. International Conference: Public Management in 21st century: Opportunities and challenges, Macau, China, 22-23 October 2010. DOI: 10.2139/ssrn.1669902

Matei, A. I., \& Matei, L. (2011). Corruption, Public Integrity and Globalization. Aspects and trends in South-Eastern European States. Paper presented at the 33rd EGPA Annual Conference 6-10 September 2011, Bucarest, Romania.

Meier, A. (2010). Governance, Structure and Democracy: Luther Gulick and the Future of Public Administration. Public Administration Review, 70(S1), 284-291. DOI: 10.1111/j.1540-6210.2010.02288.x

Metcalfe, L. (1994). International Policy Co-Ordination and Public Management Reform. International Review of Administrative Sciences, 60(2), 271-290. DOI: $10.1177 / 002085239406000208$

Mintzberg, H. J. (1979). The Structuring of Organizations: A Synthesis of the Research. Englewood Cliffs, NJ: Prentice Hall.

OECD. (2004). Co-ordination at the centre of government: The functions and organisation of the government office. Comparative analysis of OECD Countries, CEECs and Western Balkan countries (Sigma Paper No. 35). Paris: OECD Publishing. DOI: $10.1787 / 5 \mathrm{kml60v} 4 \times 2 \mathrm{f6}$-en

OECD. (2007). The role of ministries in the policy system: Policy development, monitoring and evaluation (Sigma Paper No. 39). Paris: OECD Publishing. DOI: $10.1787 / 5 \mathrm{kml} 60 \mathrm{qkg} 9 \mathrm{~g} 7$-en

OECD. (2008). Specialized Anti-Corruption Institutions: Review of Models. Paris: OECD Publishing.

Painter, M. (1981). Central agencies and the coordination principle. Australian Journal of Public Administration, 40(4), 265-280.

DOI: $10.1111 / \mathrm{j} .1467-8500.1981 . t b 00519 . x$

Peach, I. (2004). Managing Complexity: The Lessons of Horizontal Policy-Making in the Provinces. Saskatchewan Institute of Public Policy, Spring-Summer 2004.

Pedersen, K. H., \& Johannsen, L. (2004). Corruption: Causes, Commonalities and Consequences: Comparing 15 Ex-Communist Countries. Paper prepared for the 13th NISPAcee Annual Conference Democratic governance for the 21st century: challenges and responses in CEE countries, 19-21 May 2004, Moscow, Russia.

Pedersen, K. H., \& Johannsen, L. (2006). The Rise of Anti-Corruption Policies. Paper prepared for the 17th NISPAcee Annual Conference, State and Administration in a Changing World, 14-16 May 2009, Budva, Montenegro.

Pelkonen, A., Teräväinen, T., \& Waltari, S.-T. (2008). Assessing policy coordination capacity: higher education, science, and technology policies in Finland. Science and Public Policy, 35(4), 241-252. DOI: 10.3152/030234208X308854 
Petak, Z. (2006). Policy in a Transitional Context: Performing Decentralization in Croatia. In: H. K. Colebatch (Ed.), The Work of Policy: An International Survey. Lanham: Lexington Books.

Petak, Z. (2009). Oblikovanje javnih politika u Hrvatskoj i problem policy koordinacije. Anali Hrvatskog politološkog društva, 5(1), 263-273.

Petak, Z. (2015). Evidence-Based Policy Making and the Implementation of the Regulatory Impact Assessment in Croatia. Management and Business Administration, 23(2), 147-162. DOI: 10.7206/mba.ce.2084-3356.146

Petak, Z., \& Petek, A. (2009). Policy analysis and Croatian public administration: the problem of formulating public policy. Politička Misao 46(5), 54-74.

Peters, G. B. (1998). Managing horizontal government. The politics of coordination. Canadian Centre for Management Development, Research Paper No. 21, January 1998.

Peters, G. B. (2004). The Search for Coordination and Coherence in Public Policy: Return to the Center? Retrieved 15. 2. 2015, from http://userpage.fu-berlin. de/ffu/akumwelt/bc2004/download/peters_f.pdf

Peters, G. B. (2005). Concepts and theories of horizontal policy management. 10th International Congress CLAD-a, Santiago, Chile, October 2005. Retrieved 15. 2. 2015, from http://www.clad.org.ve/congreso1010i:html

Peters, G. B. (2009). Toward policy coordination: alternatives to hierarchy. Policy \& Politics, 41(4), 569-584. DOI: 10.1332/030557312X655792

Peters, G. B. (2015). Pursuing Horizontal Management: The Politics of Public Sector Coordination. Lawrence: University Press of Kansas.

Pollitt, C. (2003). Joined-up Government: a Survey. Political Studies Review, 1(1), 34-49. DOI: $10.1111 / 1478-9299.00004$

Pollitt, C., \& Bouckaert, G. (2004). Public Management Reform: A Comparative Analysis. Oxford: OUP.

Pollitt, C., \& Talbot, C. (Eds.). (2004). Unbundled Government: A critical analysis of the global trend to agencies, quangos and contractualisation. London: Routledge.

Pusić, E., et al. (1998). Upravni sistemi, sv. I. Zagreb: Grafički zavod Hrvatske, Pravni fakultet u Zagrebu.

Sabatier, P. A. (1986). Top-Down and Bottom-Up Approaches to Implementation Research: A Critical Analysis and Suggested Synthesis. Journal of Public Policy, 6(1), 21-48. DOI: 10.1017/S0143814X00003846

Saner, R., et al. (2008). Government Governance (GG) and Inter-Ministerial Policy Coordination (IMPC) in Eastern and Central Europe and Central Asia. Public Organization Review, 8(2), 215-231. DOI: 10.1007/s11115-008-0051-x

Schimmelfennig, F., \& Sedelmeier, U. (Eds.). (2005). The Europeanization of Central and Eastern Europe. Ithaca, NY: Cornell University Press.

Staronova, K. (2002) Analysis of The Policy Making Process in Slovakia (Final Research Paper). Retrieved from http://www.policy.hu/staronova/ FinalResearch.pdf

Sumpor, M., \& Starc, N. (2003). Pro-Active Regional Development Policy: A Croatian Case. Paper presented at the ERSA 2003 Congress Peripheries, Centres, and Spatial Development in the New Europe, Jyväskylä, Finland, 27-30 August 2003. 
Temmes, M. (2006). The Horizontal Tasks of the Government. Retrieved 15. 2. 2015, from http://unpan1.un.org/intradoc/groups/public/documents/ nispacee/unpan025548.pdf

The World Bank (2000). Anti-Corruption in Transition: A Contribution to the Policy Debate. The World Bank: Washington, DC. Retrieved 15. 2. 2015, from http://info.worldbank.org/etools/docs/library/17506/contribution.pdf

Thompson, J. D. (1967). Organizations in Action. New York: McGraw-Hill.

Verhoest, K., Bouckaert, G., \& Peters, B. G. (2007). Janus-faced reorganization: specialization and coordination in four OECD countries in the period 19802005. International Review of Administrative Sciences, 73(3), 325-348.

DOI: $10.1177 / 0020852307081144$

Weber, E. P., \& Khademian, A. M. (2008). Wicked Problems, Knowledge Challenges, and Collaborative Capacity Builders in Network Settings. Public Administration Review, 68(2), 334-49. DOI: 10.1111/j.1540-6210.2007.00866.x

Zubek, R., \& Staronova, K. (2012). Organizing for EU Implementation: The Europeanization of Government Ministries in Estonia, Poland and Slovenia. Public Administration, 90(4), 937-956. DOI: 10.1111/j.1467-9299.2012.02074.x 


\subsection{Izvirni znanstveni članek}

\section{Koordiniranje politike $v$ tranzicijskih državah: primer Hrvaške}

Organizacijska teorija pravi, da specializacija kot tudi horizontalna in vertikalna diferenciacija upravne dejavnosti v moderni državi vodijo k večji potrebi po koordinaciji. Novo javno upravljanje je zaostrilo trend specializacije z zagovarjanjem diferenciacije, delegacije, devolucije in decentralizacije neodvisnih agencij, zunanjega izvajanja organizacij zasebnega sektorja ter privatizacije javnih storitev. Procesi fragmentacije državne uprave, politična decentralizacija kot tudi povečano mednarodno sodelovanje $v$ okviru globalizacije in evropeizacije so povečali problem koordiniranja javnih politik in doseganja ciljev javne uprave. Poleg tega je vzniknilo lotevanje več perečih družbenih problemov znotraj novih medsektorskih politik, ki zadevajo obstoječa področja politik in ministrske resorje, kot so varovanje okolja, enakopravnost spolov, ekonomska konkurenca ali boj proti korupciji. Povečevanje števila avtonomnih agencij ter ločevanje političnih in upravnih nalog v različnih upravnih organizacijah (ministrstva v nasprotju z agencijami), pojav horizontalnih in medsektorskih politik kot tudi večnivojsko upravljanje so ustvarili ogromen pritisk na politično-upravni sistem, kar zadeva koordiniranje aktivnosti in organizacij za doseganje istih političnih ciljev. Odgovor na to je združevanje stebrov upravne dejavnosti v okviru celostnega, združevalnega ali holističnega upravljanja.

Problem koordinacije je posebej pomemben pri formulaciji in implementaciji posamezne politike. Nezadostna koordinacija med političnimi deležniki v procesu formuliranja politike in neuspešna koordinacija implementacijskih aktivnosti se lahko označita kot glavni problem politike. Obstaja več dimenzij koordiniranja politik, ki vključujejo razlike med pozitivnimi in negativnimi vidiki koordinacije, med vertikalnimi in horizontalnimi linijami koordinacije, med kratkoročnimi in dolgoročnimi vidiki doseganja koherentnosti političnih ciljev ter politično in upravno koordinacijo. Ker mehanizem upravljanja ni enovito telo, ampak je sestavljeno iz organizacij, ki so v različni meri vzajemno medsebojno povezane, se izvajanje koordiniranja odraža v učinkoviti interakciji med različnimi stranemi v prizadevanju za skupno delovanje k skupnemu cilju. Pri tem politično koordiniranje vključuje različne procedure in strukture, kot so učinkovit svetovalni sistem in vloga politične ekspertize v vladnem uradu, vloga kabinetnih odborov pri koordiniranju politik, ustanovitev osrednjih agencij, koordinacijska prizadevanja med ministrstvi in še mnoge druge oblike. V literaturi se široko uporablja Metcalfeova klasifikacija političnega koordiniranja, ki se ukvarja s hierarhično razvitimi fazami političnega koordiniranja in ki meri sposobnost koordinacije z devetimi dimenzijami. 
V demokracijah v razvoju je problem političnega koordiniranja še bolj očiten. Graditev ustreznih koordinacijskih struktur in razvijanje instrumentov koordiniranja sta bila med glavnimi elementi državnih in upravnih reform. Podedovani koordinacijski mehanizmi, ki so temeljili na prehodu od odločanja komunistične partije k odločanju državnih institucij prek politično imenovanih oseb v političnih telesih in upravi, se niso mogli odzvati na novo politično, družbeno in ekonomsko okolje v tranzicijskem obdobju ter procese odpiranja družbi, demokratizacije, evropeizacije in internacionalizacije. Problem koordiniranja politike $v$ fazah formulacije in implementacije utegne biti povezan tudi s pomanjkanjem (ali z odsotnostjo) strateškega upravljanja $\checkmark$ vladi. $\vee$ novem političnem in ekonomskem kontekstu je vzniknila potreba po razvoju in institucionalizaciji koordinacijskih struktur in funkcij, ki bi horizontalno in vertikalno povezale upravljanje ter zagotovile pregledno in učinkovito sprejemanje in uveljavljanje odločitev.

Koordiniranje je postalo pomembno tudi v Hrvaški, eni od vzhodnoevropskih tranzicijskih držav in novi članici EU-ja (od leta 2013). Sistem političnega koordiniranja na Hrvaškem na splošno trpi zaradi več institucionalnih in strukturnih primanjkljajev, kot so pomanjkanje osrednje enote za razvoj politike, šibka politična ekspertiza, formalizacija procedur, odsotnost stabilne in transparentne sheme razreševanja razlik med ministrstvi ter zlasti šibka ex-ante koordinacija med ministrstvi.

Raziskava, predstavljena v tem članku, je osredotočena na opis koordiniranja $v$ treh ločenih politikah na Hrvaškem - v regionalni razvojni politiki, protikorupcijski politiki in politiki e-uprave - v obdobju pred članstvom v EU-ju. To so nove politike, ki so nastale po letu 2000 in so v različni meri povezane s pristopanjem k EU-ju, izkazujejo pa značilnosti medsektorskih politik. Po drugi strani se te tri politike razlikujejo v mnogih vidikih, kot so ugled politike, vrsta politike, udeležba akterjev, mehanizmi, ki se uporabljajo za koordinacijo, ter vloga EU-ja pri razvoju politike. Poseben poudarek je namenjen razvoju političnih in upravnih struktur koordinacije, akterjem, vključenim v koordiniranje politik, ter vplivu EU-ja na razvoj in uspešnost koordinacije.

Podatki, pridobljeni z intervjuji ter pravno in politično analizo, kažejo, da na najvišjih upravnih in političnih ravneh še naprej obstaja problem koordinacije. Regionalna politika je del ekonomske politike in je večinoma vertikalno koordinirana, medtem ko sta protikorupcijska politika in politika e-uprave medsektorski politiki, kjer prevladuje horizontalno koordiniranje akterjev na državni ravni. Smer koordiniranja (vertikalna nasproti horizontalni) in dejstvo, da politične sile za različnimi ravnmi (nacionalno, subnacionalno) zasledujejo svoje ločene politične (in ekonomske) interese, določata proces oblikovanja in uveljavljanja politik. Medtem ko so pri regionalni politiki najmočnejši subnacionalni akterji in akterji zasebnega sektorja, ki imajo največjo sposobnost vplivanja na rezultate, pa pri protikorupcijski politiki pritisk na oblikovanje in uveljavljanje politike izvajajo organizacije civilne družbe ob pomoči zunanjih donatorjev. V razvoj politike e-uprave so vključeni akterji zasebnega sektorja, 
ki imajo poseben interes za sodelovanje z vlado pri razvoju ICT rešitev, a tudi kot uporabniki upravnih storitev, ki podpirajo spremembe za hitrejšo in učinkovitejšo upravo. $V$ vseh treh primerih močno vlogo igrajo domači strokovnjaki (znanstveniki, svetovalci), še zlasti v fazi oblikovanja politik, saj ima vlada premalo lastnih strokovnjakov. Na vse tri politike je vplivala EU z dvema ločenima fazama - prvi poizkusi za uvedbo političnih in koordinacijskih mehanizmov so bili zmerno uspešni; pestile so jih začetniške napake, imeli so šibek institucionalni okvir, nerazvite strategije in vprašljivo politično podporo. Po začetku pogajanj o članstvu v EU-ju je bila razvita bolj izpopolnjena politika, vendar še vedno pomanjkljiva pri strateškem upravljanju in z zmerno uspešnim koordinacijskim mehanizmom. Toda pritisk EU-ja je bil različen od formalnega pritiska pri regionalni politiki za oblikovanje in uveljavitev strateškega in pravnega okvira do političnega pritiska pri protikorupcijski politiki in precejšnjega manevrskega prostora za uveljavitev politike e-uprave. Glede na koordinacijske strukture in mehanizme so bile pri vseh treh politikah sprejete strategije, najprej v obliki splošne izjave ali programskih dokumentov, kasneje v bolj izdelanih verzijah, a še vedno ob pomanjkanju jasnih meril in kazalnikov. Nepripravljenost za razvoj strategij, ki bi omogočile ustrezno koordinacijo, lahko kaže ne le na šibko strokovnost in pomanjkljivosti v strateškem upravljanju, temveč tudi na nepripravljenost politike, da bi izkazala iskreno zanimanje za uspešnost oblikovanja in uveljavljanja politik. Čeprav bi torej z lestvice političnega koordiniranja izhajalo, da je strategija višja raven koordinacije, hrvaški primer kaže, da je lahko kljub obstoju strategije koordinacija nezadostna. Nakazuje tudi nizko strateško sposobnost institucij in določeno napačno interpretiranje vloge strategije. Razen tega so se politične in upravne strukture koordiniranja pogosto spreminjale, kar je negativno vplivalo na uspešnost politike. Kljub temu hkrati doseženi napredek kaže, da večja politična pomembnost vprašanja pozitivno vpliva na razvoj koordinacijske strukture na politični ravni in močnejšega političnega vodenja in verjetno prispeva tudi k večji uspešnosti politike. 